\title{
Small matching grants for women entrepreneurs: lessons from the past recession
}

\author{
Stjepan Srhoj • Bruno Škrinjarić $(\mathbb{D} \cdot$ Sonja Radas • \\ Janette Walde
}

Accepted: 10 June 2021 / Published online: 1 August 2021

(C) The Author(s), under exclusive licence to Springer Science+Business Media, LLC, part of Springer Nature 2021

\begin{abstract}
During the economic slowdown caused by the financial crisis in 2008, grants for entrepreneurs were made available to support economic development. Whether such a policy instrument is effective for business development is a highly relevant question in the aftermath of the COVID-19. We evaluate the causal effects of small business development matching grants using a quasi-experimental approach. The grants were exclusively targeted to women entrepreneurs and provided during the recession after the financial crisis. Our findings demonstrate an increase in bank loans and a positive impact on turnover, value-added, capital, employment, and overall factor productivity for more experienced women entrepreneurs. As the grants are too small to have direct economic effects or indirect effects via the certification effect, they alleviate time and information constraints of women entrepreneurs. The costbenefit analysis shows an increase in value-added that outweighs the scheme-related costs.
\end{abstract}

\section{S. Srhoj}

Department of Economics and Business, University of Dubrovnik, Lapadska obala 7, 20000 Dubrovnik, Croatia

\section{B. Škrinjarić $(\square) \cdot S$. Radas}

The Institute of Economics, Zagreb, J. F. Kennedy Square 7, 10000 Zagreb, Croatia

e-mail: bskrinjaric@eizg.hr

J. Walde

Department of Statistics, Faculty of Economics and Statistics, University of Innsbruck, Universitaetsstr. 15, 6020 Innsbruck, Austria
Plain English Summary This study evaluates the effect of small public grants for women entrepreneurs. Grants were used for childcare and business consultancy costs to alleviate time and information constraints of women entrepreneurs. Benefiting from these grants resulted in higher bank loans. The women entrepreneurs on average invested more money in capital and had better performance measures like turnover and valueadded. The effect was particularly evident among more experienced women entrepreneurs. The cost-benefit analysis shows grant-induced increase in value-added outweighs the scheme-related costs. The study implies small public grants for women entrepreneurs increase small firms' growth, and these grants are in addition a cost-effective policy tool.

Keywords Women entrepreneurship - Gender financing gap · Policy evaluation - Business development grant . Recession

JEL Classifications B54 $\cdot \mathrm{H} 43 \cdot \mathrm{H} 81 \cdot \mathrm{J} 16 \cdot \mathrm{L} 26 \cdot \mathrm{L} 38$

\section{Introduction}

In times of economic slowdown, small and undercapitalized firms are overly affected. Small firms experienced disproportionate job losses during the recession after the financial crisis in 2008, especially womenowned firms, and this is likely to be repeated in the post-COVID-19 recession (Brookings, 2020). Usually, countries use various public policy instruments to 
minimize the damage to firms in recession, but in the coming years, excessive public funding may be difficult to sustain and may not be perceived as socially balanced. Hence, it is necessary to use policy instruments that can cover a larger population of eligible firms by administering small sums of money but still achieving significant improvements. In this study, we discuss one such instrument aimed at micro- and small womenowned firms.

The setting of this study is Croatia, which, due to its uniquely long recession period (2009-2014), is ideal for studying the effectiveness of policies during a recession. Expansion of Croatian economy, which started back in the early 2000s, ended in late 2008 with the financial crisis. However, unlike some other Central European economies that returned to the growth path of recovery within a year or two, Croatia needed 6 years, running up to the end of 2014, to get back on its growth path. To support the economy, the Croatian Ministry of Entrepreneurship and Crafts introduced, among others, the analyzed grant scheme at the onset of the recession in 2008 and it ran until 2012. This means that firms in our dataset were still operating in a recessionary climate several years after receiving the grant. The length of this recession gives us a unique opportunity to assess the effects of the policy measure under recessionary conditions, as the grant effects are not likely confounded with effects of a general macroeconomic growth. The target group of the grant scheme consisted exclusively of women entrepreneurs in micro- and small enterprises. The grants financed childcare costs, preparation of documentation for bank loans, and development of business plans. A particularity of the grant scheme was that the administered grants were quite small in amount and were not intended to deliver any direct effects on firm performance. Instead, grants were targeted at the demand of women entrepreneurs for external financing by helping them to prepare loan applications or otherwise raise funds.

Apart from supply-related factors that are in general not under entrepreneurs' control (Bellucci et al., 2010; Carter et al., 2007; Foss et al., 2019; Neumeyer et al., 2018), there are several factors that influence the demand for business finance, which is generally lower for women entrepreneurs than for their male counterparts (Croson \& Gneezy, 2009; Huang \& Kisgen, 2013). This is partly explained by women's greater risk aversion to taking out a loan (Block et al., 2015) or lack of financial literacy (Coleman, 2002). Studies have also shown that women are discouraged from applying for funding because they expect their applications to be rejected (Robb $\&$ Walken, 2002). The design of the grant scheme under study precisely addresses these factors specific to women entrepreneurs to achieve a greater demand for financial resources. The policy instrument provided women entrepreneurs with expertise and additional time needed to apply for financing, thus helping them to overcome potential financial literacy problems as well as risk aversion. This is particularly useful in the context of economic recession and increased market uncertainty, when greater risk aversion of women entrepreneurs becomes advantageous as banks seek to hedge risks by favoring lenders that are more conservative. ${ }^{1}$ Thus, we end up with a paradox that the risk aversion of women entrepreneurs prevents them from seeking external financing, although this risk aversion is precisely what may increase their chance of obtaining external financing, as banks perceive them as less risky (Cowling et al., 2019).

In this study, we seek to answer the following research question: Do small grants provided to micro- and small firms achieve significant impact on firm behavior? In doing so, we add to the literature with two main contributions. Firstly, a recent systematic literature review highlights the need for impact evaluations of public grants (Dvouletý et al., 2020). In particular, very little is known about the impact of policies to promote women entrepreneurship (Cardella et al., 2020), both in terms of the overall effectiveness of the individual policies (OECD, 2004; Pandey \& Amezcua, 2020) and in terms of the impact on access to financial capital (Brush et al., 2019; Leitch et al., 2018). Our study is among the first to provide quasi-experimental evidence of effectiveness of policies specifically targeting women entrepreneurs. Secondly, we delve deeper into the problem of the size of grants and whether small grants can be designed in a way to have an impact on firm behavior. Even if the amount of the grant was small, the objective and design of the grant scheme were intended to have a positive impact on the demand for capital. Once the capital constraint is released, firms can improve their

\footnotetext{
${ }^{1}$ Women entrepreneurs' risk aversion is not the only criterion used for loan evaluation. Carter et al. (2007) name a variety of evaluation criteria. They find no gender discrimination concerning these criteria except that female loan applicants are more likely to be assessed on whether they had undertaken sufficient research into the business compared to male applicants.
} 
performance, which leads to a variety of positive effects. A peculiarity of the analyzed grant scheme was not its direct easing of capital restrictions, but its design to encourage women entrepreneurs to raise money in a recessionary environment.

Although this study analyzes a grant scheme targeted specifically at women entrepreneurs, the grant design can be generalized and tailored to sets of entrepreneurs that face constraints in social, human, and financial capital. Small grants that are designed to induce desired behavioral changes can be a useful tool for policy makers, especially when budgets for public grant programs are limited, as can be expected in prolonged recessions.

To identify the grant scheme effects, we employ a rich dataset including financial and structural data on the universe of Croatian firms and combine it with data on women entrepreneurship grants. Using a matching difference-in-differences estimation approach, we find positive effects on bank loans and several performance indicators. Additionally, we identify heterogeneous grant effects due to women entrepreneurs' age, as a proxy for their experience, and demonstrate that grants had stronger effects on the survival of young women's firms, while all other effects (output growth; labor, capital, and intermediate input growth; long-term productivity) were much more pronounced for more experienced women entrepreneurs. In fact, using the estimates in a "back-of-the-envelope" cost-benefit analysis, we show that grant benefits outweigh public grant costs by a factor of about 2 in the short and long run for more experienced women. The positive effects on firm performance demonstrate a success of the grant scheme, which stimulated women entrepreneurs' demand for bank loans or other financing.

The remainder of the paper is organized as follows. Section 2 presents the theoretical background and our hypotheses, and Section 3 describes the institutional setting. Section 4 presents data and methodology, followed by the results in Section 5. Lastly, Section 6 provides the discussion and conclusions.

\section{Theoretical background and hypotheses}

\subsection{Grant scheme}

The investigated grant scheme targeted exclusively women entrepreneurs of micro- and small firms (SMEs). The potential grant recipients had to be registered in Croatia. Eligible SMEs had to have a surplus recorded in the previous year of business and at least one full-time employee. In addition, having no debts towards the state or employees was a prerequisite (Table 8 in the Appendix). Thus, eligible to apply for the grant were 12,583 firms in year 2008, 13,539 firms in 2009, 14,485 firms in 2010, and 15,016 firms in 2011. However, only a small number of firms (1284 firms) were awarded a grant. The rejection rate was about $60 \% .^{2}$

The grants were designed as matching grants, i.e., the grant co-financed $75 \%$ of the project value (VAT excluded), and firms had to finance the remaining $25 \%$ (and VAT) from private funds. Common activities that were co-funded by the grant included: (1) development of a business plan and consulting services, (2) entrepreneurial training, (3) purchase of equipment, tools, and inventory, (4) preparing documentation for bank loans, and (5) babysitting and kindergarten costs.

After the public call, firms submitted applications describing their planned activities along with their financial statements for the previous year. The Ministry's expert team conducted the evaluation, taking into consideration the conditions elaborated above and the qualifications of the applicants.

In general, grants can affect firm output both directly and indirectly. They can directly ensure the inflow of needed capital that can boost firm output (Cerqua \& Pellegrini, 2017; Špička, 2018). Grants can also work indirectly by reducing information asymmetry via the certification effect, where awarding a grant acts as a quality stamp and indicates that the firm's project has great potential and high chances of success. This in turn reduces the cost of capital and increases the probability of obtaining a loan, thus increasing output (Martí \& Quas, 2018; Srhoj et al., 2021). However, the analyzed grants are not likely to produce any direct effect or any indirect effect via certification. There are two main reasons for this. Firstly, the analyzed grant amounts were too small (on average 1636 EUR) to have any direct effect on firm output or to produce any kind of signal to lenders of the high potential of an enterprise. Carter et al. (2007) show that bank loan officers may consider any obtained grants in their allocation decision,

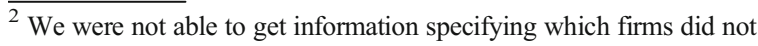
receive grant funding; only the rejection rate was confirmed in interviews with the Ministry of Entrepreneurship and Crafts and can be found in the official report of the Ministry (MINPO, 2013, 2014).
} 
but the weight of these criteria is only marginal in the overall assessment. ${ }^{3}$ Secondly, the analyzed grants were not intended for a specific investment project, for which the bank was supposed to provide additional credit. There was no project outline that was "certified" through obtaining the grant as a sign of high probability of success. Any impact on firm performance is more likely achieved by influencing the factors that hold back the demand for business finance of women entrepreneurs, i.e., by influencing their behavior. Resulting additionality in the demand for financing can either be observed through an increase in bank loans when official financing was chosen by the women entrepreneurs or through an increase in capital if informal sources of funding were used (Lim \& Suh, 2019).

\subsection{Theoretical background}

The analyzed grant scheme gives recipients access to needed time and skills, thus supporting them in their decision-making process and/or the necessary preparation to make investments. It is well documented that women entrepreneurs approach and run their firms differently than their male counterparts (Foss et al., 2019; Henry et al., 2017). Compared to men, women entrepreneurs are more sensitive to social, family-related, and other nonfinancial concerns that significantly influence their business choices (Ahl \& Nelson, 2015; Cardella et al., 2020; Friedson-Ridenour \& Pierotti, 2019; Henry et al., 2017). In particular, Berge and Pires (2020, p. 897) show that time constraint is a serious obstacle for women entrepreneurs, as "the burden of domestic obligations that fall on women ... necessarily restrict their capacity and potential as entrepreneurs." The observed grant scheme allows recipients to invest more time in their business by financing childcare and/or investigating investment possibilities with the help of an expert.

In terms of human capital, women are less likely to be educated in science, technology, engineering, or mathematics (STEM), which predestines them to work and/or set up their businesses in low-technology sectors, often characterized by relatively low growth (Carter

\footnotetext{
3 To check the accuracy of that assumption, we conducted interviews with bank loan officers from the two largest banks in Croatia. Both officers, who oversee small business loans, confirmed that grants such as the ones we studied do not provide more credit points for the applicant in the overall loan eligibility assessment. The names and affiliations of the two officers are known to the reviewers and the editor, but are not published here.
}

et al., 2015). In terms of social capital, women also rarely hold executive positions before starting their own business, making them less likely to belong to influential business networks that provide access to contacts, resources, and relevant information (Foss et al., 2019; Neumeyer et al., 2018). Although the observed grant scheme cannot finance any long-term increase in human and social capital, it enables women entrepreneurs to take advantage of advisory services and thus brings the necessary skills to improve decisionmaking.

Apart from difficulties with human and social capital, women entrepreneurs also face greater obstacles in securing financial capital compared to male entrepreneurs (Henry et al., 2017). For example, it has been shown that lack of social capital has negative consequences on securing external financing (Foss et al., 2019; Neumeyer et al., 2018). Guzman and Kacperczyk (2019) show that females are 63\% less likely than males to obtain external financing in terms of risk capital, and the most significant part of the gap derives from differences in gender. In addition, banks may ask for higher loan collateral from a woman (Bellucci et al., 2010), or women may have to pay higher interest rates (Alesina et al., 2013). The observed grant scheme helps by allowing women entrepreneurs to hire short-term consultants to assist them with bank loan applications to facilitate an application after a detailed evaluation of the firm's situation.

Numerous studies provide evidence that women are on average more risk-averse than men (Borghans et al., 2009; Croson \& Gneezy, 2009), and thus "gender" may impede investments profitable for the firm. Evidence of the latter can be found in finance and entrepreneurship research. Studies suggest that male leaders are more likely than female leaders to pursue business opportunities (Ahl \& Nelson, 2015), that female-led firms exhibit more risk-averse capital allocation behavior than maleled firms (Faccio et al., 2016), and that the chances of getting a loan approved are lower for less experienced women entrepreneurs than for their male counterparts (Bellucci et al., 2010). However, the more familiar a woman is with a specific type of decision problem and the more experienced she is in the corresponding domain, the more risk-accepting she will be (Schubert et al., 1999). The degree of risk aversion of an individual is influenced by many factors, such as confidence, information processing, and experience (Fréchette et al., 2017), and this is where policy activities, such as the 
presently analyzed grant scheme, come into play. Terjesen et al. (2016) point out that efforts must be made through policies to help women to develop confidence and to spot and pursue opportunities. Policy measures should also reduce women's fear of business failure, which is a major obstacle to initial but also sustainable entrepreneurship (Bosma, 2013).

The observed grant scheme cannot produce direct effects on performance; however, by allowing women entrepreneurs to invest more time in their work and/or to acquire needed skills (through short-term consulting), the scheme has an ability to improve recipients' decision-making, lower their risk aversion to finance, and alter their unwillingness to seek bank loans. In turn, these behavioral changes have the potential to improve firm performance.

\subsection{Hypotheses}

Given the possible channels through which the analyzed grant scheme may have an impact on firm behavior, we operationalize our research question into feasible hypotheses. First, we postulate that small grants cause positive effects on firm performance. We expect higher performance measures compared to firms not obtaining the grant but otherwise having the same prerequisites. Evidence in the literature is already available, but for larger grant amounts with the objective to directly increase various performance measures (Howell, 2017; Criscuolo et al., 2019). In addition, especially for younger firms, investment decisions may increase the probability of firm survival (Pellegrini \& Muccigrosso, 2017; Srhoj et al., 2021):

Hypothesis 1 . The grant scheme has positive effects on firm performance and survival.

As the grant scheme helped entrepreneurs to gain the time and skills needed to make investment decisions, we expect that entrepreneurs have a larger demand for external funding and that they will be successful in raising it. Therefore, we expect to observe an increase in bank loans, which serve as a means for future firm improvement (Srhoj et al., 2020; Srhoj et al., 2021). More specifically:

Hypothesis 2. The grants increase the demand for bank loans and, consequently, improve firm performance.

Since prior studies show that the owners' previous professional experience has a significant influence on the performance of their firms (Colombo \& Grilli, 2005;
Schulz et al., 2013; Backman, 2014), as individuals with higher industry-specific skills are better able to exploit business opportunities (Ganotakis, 2012), we investigate heterogeneous effects concerning less and more experienced women entrepreneurs. As more experienced women had an opportunity to accumulate larger social and human capital, we postulate that they can extract more benefits from participation in the grant scheme:

Hypothesis 3. The positive effects are pronounced for more experienced women entrepreneurs.

Finally, we address the cost effectiveness of this scheme. Even if positive grant effects on average can be observed, the question arises whether the amount of support was nevertheless too small to measure substantial macroeconomic effects, substantial at least on the scale of costs caused. Grant effects can be larger, equal, or lower than the direct grant scheme costs. Based on prior research, public grants for R\&D (Howell, 2017), industrial policy grants (Criscuolo et al., 2019), public grants for exporters (Srhoj \& Walde, 2020), and public development grants for SMEs older than 5 years (Srhoj et al., 2020) all provide evidence of more benefits than direct grant costs:

Hypothesis 4. The estimated benefits outweigh the public costs of the grant scheme.

This is the last hypothesis we investigate under restrictive conditions with a cost-benefit analysis. We use average treatment effects on the treated firms to calculate macro-effects. While awarded grants may have also generated positive spillovers to other firms, such as consultants, suppliers of equipment, or kindergartens, we do not include such additional benefits. Furthermore, we do not consider any costs caused by the administration of the grant system.

\section{Institutional setting}

The Republic of Croatia adopted the Strategy for Development of Women Entrepreneurship for the 20092013 and the 2014-2020 period, together with their Action Plans (MINPO, 2014). The grant strategy aimed to reduce the finance gap between women and men entrepreneurs. Table 1 gives evidence for the finance gap by providing the average amount of bank loans acquired by men versus women entrepreneurs. The Ministry of Entrepreneurship and Crafts of the Republic of Croatia (hereinafter, Ministry) oversaw most grant 
schemes in Croatia. ${ }^{4}$ The grant schemes under the umbrella of this Ministry encompassed various competitiveness grant schemes (Srhoj et al., 2021). Women entrepreneurs did not make satisfactory use of the Ministry's public funding programs. In 2012, 37\% of all entrepreneurs in Croatia were women (European Commission, 2014), but only $19.5 \%$ benefited from public subsidies, although additional points were awarded to women entrepreneurs in the selection process (MINPO, 2014). To increase the allocation of grants to women, the Ministry launched several grant programs in the 2008-2012 period, targeting exclusively women entrepreneurs of micro and small firms (details are given in Tables 8, 9, and 10 in the Appendix).

The effectiveness of these public funds has not yet been rigorously evaluated (MINPO, 2014). Critics argue that government policies in Croatia were rather ineffective in spurring firm competitiveness (Bartlett, 2016; Srhoj et al., 2021). Bartlett (2016) concludes that policy measures did not have the desired impact on the competitiveness of Croatia's economy. He takes the Global Entrepreneurship Monitor's total early-stage entrepreneurial activity (TEA) index for women and men entrepreneurs to demonstrate considerable gender differences. The differences in the TEA index were rather large and persistent for the 2006-2014 period in Croatia (Bartlett, 2016), showing stagnation in the development of women entrepreneurship.

Tables 9 and 10 in the Appendix show that women entrepreneurship grant schemes encompassed 1284 grants over the 2008-2012 period, with a total amount of 15,605,987 HRK (about 2,104,089 EUR), and that on average 12,154 HRK per firm (about 1636 EUR) was awarded.

\section{Data and methodology}

\subsection{Data}

Three datasets were merged: financial and structural data on the population of Croatian enterprises for the 2005-2016 period, obtained from the Croatian Financial

\footnotetext{
${ }^{4}$ The policy basis for these grant schemes can be found in the policy documents entitled Operational Plan of Incentives for Small and Medium Entrepreneurship (OPPMSP 2008, 2009, 2010, 2011) and Entrepreneurial Impulse: Plan of Incentives for Entrepreneurship and Craftsmanship (MINPO, 2013).
}

Agency (hereinafter, FINA); data on women entrepreneurship grants in the 2008-2012 period, obtained from the Ministry; and data on demographic information on entrepreneurs, obtained from the public register of incorporated companies (hereinafter, Companies Register).

The FINA dataset includes balance sheet and profit and loss statement data covering 300 variables for the universe of Croatian incorporated firms, as well as firm characteristics such as region, size, industry sector, firm ID, and year of the report. On the other hand, the Ministry dataset includes the name of the grant recipient, the amount of the grant given, and the year the grant was received. The Companies Register contains identifiers for entrepreneurs, together with their characteristics such as age, gender, and their position within the firm.

After merging the FINA and Ministry datasets, data are available on 196,300 firms, 1274 of which obtained the analyzed grants. We remove all medium and large firms, foreign-owned firms, and state-owned firms, as these were not eligible as recipients for the analyzed grants. For the same reasons, we remove all firms that reported a negative operating surplus, firms with unpaid debts towards the state or employees, and firms with a male ownership structure in the year before receiving a grant. We exclude firms having either no employees or zero turnover. ${ }^{5}$ At this point, our sample is reduced to 59,299 firms. Firms receiving grants in the year of incorporation are also dropped, as we have no previous financial records for these firms. Finally, we exclude all grant recipients in 2012, as these grants targeted a very small number of firms $(n=35)$. These firms were awarded heftier grant amounts than in previous grant schemes - on average 14 times larger grant amounts than the ones up to 2012 (Tables 9 and 10) - and received $100 \%$ support as opposed to $75 \%$ support in the 2008-2011 period (Table 8). Due to their characteristics, these grants could have direct effects also. Our

\footnotetext{
${ }_{5}^{5}$ These observations are mostly craft businesses. In line with existing papers (e.g., Vitezić et al., 2018), we discard craft businesses, as no financial data are available for these organizations. Craft businesses report their income based on the Income Tax Law (OG 177/2004), while limited liability firms must keep accounting records at a detailed level according to the Accounting Act, Croatian and International Financial Reporting Standards, and International Accounting Standards.
} 
Table. 1 Differences in amount of bank loans dependent on the sector between men- and women-owned firms

\begin{tabular}{|c|c|c|c|c|c|c|}
\hline \multirow[t]{2}{*}{ Industries (NACE 1-digit) } & \multicolumn{3}{|c|}{ Only men-owned firms } & \multicolumn{3}{|c|}{ Only women-owned firms } \\
\hline & $N$ & Mean & SD & $N$ & Mean & SD \\
\hline Agriculture, forestry, fishing & 16,565 & 179,306 & 767,043 & 2633 & 128,596 & 499,644 \\
\hline Mining, quarrying & 1552 & 251,813 & 811,504 & 174 & 156,945 & 337,293 \\
\hline Manufacturing & 76,108 & 115,327 & 734,746 & 14,090 & 62,645 & 754,441 \\
\hline Energy & 2321 & 478,796 & $3,320,313$ & 275 & 182,698 & $1,332,153$ \\
\hline Water, sewage, waste & 1966 & 272,841 & $1,213,217$ & 356 & 196,982 & 594,284 \\
\hline Construction & 80,010 & 314,377 & $7,207,257$ & 10,049 & 128,564 & 858,217 \\
\hline Wholesale, retail, motor vehicles & 168,028 & 107,148 & $1,285,320$ & 48,421 & 48,894 & 312,643 \\
\hline Transport, storage & 26,605 & 88,163 & 494,119 & 4173 & 59,263 & 359,776 \\
\hline Accommodation, food & 31,865 & 210,859 & $3,233,502$ & 8727 & 50,783 & 260,810 \\
\hline ICT & 27,627 & 35,353 & 288,903 & 5016 & 10,887 & 56,811 \\
\hline Finance, insurance & 3961 & $1,322,854$ & $12,850,392$ & 1051 & 20,640 & 188,803 \\
\hline Real estate & 14,614 & 615,995 & $3,541,202$ & 4425 & 82,954 & 947,541 \\
\hline Professional, scientific work & 75,336 & 109,913 & $2,480,010$ & 35,458 & 13,203 & 118,200 \\
\hline Administration & 17,849 & 103,072 & $2,068,780$ & 6022 & 30,187 & 186,109 \\
\hline Education & 3621 & 18,458 & 112,522 & 3705 & 10,380 & 31,976 \\
\hline Health, social work & 3892 & 56,457 & 242,977 & 3252 & 30,395 & 145,788 \\
\hline Arts, entertainment, recreation & 5115 & 146,144 & $1,158,371$ & 1256 & 115,780 & $1,825,285$ \\
\hline Other services activities & 10,156 & 21,626 & 236,681 & 9764 & 34,475 & $1,006,263$ \\
\hline Total & 567,191 & 163,261 & $3,320,297$ & 158,847 & 46,784 & 511,852 \\
\hline
\end{tabular}

Notes: Data on the universe of Croatian firms, for which gender ownership structure data are available for the period from 2008 to $2011 . N$ denotes number of firms; SD denotes standard deviation. All monetary variables are expressed in EUR. 1 EUR 7.42 Croatian kuna (HRK)

analysis thus focuses on the 2008-2011 period only. ${ }^{6}$ In this period, all analyzed grants are very homogeneous. As an identification strategy, we exclude firms also receiving other grants in the 2008-2012 period. We end up with 484 grant-awarded firms (treated firms) and 6380 potential control firms (considering the time dimension, we have 20,392 observations).

\subsection{Methodology}

The methodological approach identifies the causal effect by comparing outcomes between a treatment group and a control group (Rosenbaum \& Rubin, 1983). Treatment is usually modeled as a binary variable $D$, taking the value 1 for the treated firms and 0 for the control (nontreated, counterfactual) firms. The greatest challenge is to find a control firm that is as similar as possible for each treated firm, as firms may systematically differ in

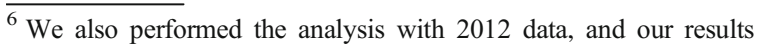
remained robust. These results are available on request.
}

both observable and unobservable characteristics (Heckman et al., 1998). To mitigate this problem, Rubin (1977) introduced the conditional independence assumption (CIA), stating that potential outcomes are independent of treatment assignment (i.e., that exposure to treatment can be considered random), given a set of observable covariates $X$, which are not affected by the treatment, i.e., $Y(D=0), Y(D=1) \perp D \mid X$, where $Y(D)$ denotes the potential outcome.

Empirically, this allows each treated firm to be matched with one (or several) control firm(s) that are as similar as possible in their pre-treatment characteristics. We estimate this similarity of treated and control firm using a propensity score. This propensity score is defined as the conditional probability of receiving treatment given pre-treatment characteristics and is estimated using a standard probit model. We restrict the propensity scores to the common support area, thus considering only firms in the intersection of the range of the propensity scores for treated and control firms. Finally, the control firm for each treated firm is selected using 
the nearest neighbor method (for the baseline scenario) without replacement. Once the control firms are matched to the treated firms, the average treatment effect on the treated firms (ATT) is estimated via $A T T=\frac{1}{N^{T}} \sum_{i \in T}\left(y_{i}^{T}-y_{i}^{C}\right)$, where $N^{T}$ is the number of treated firms and $y_{i}^{T}\left(y_{i}^{C}\right)$ is the observed outcome of the treated (control) firm $i$.

To check the robustness of our ATT findings, we conduct a placebo test and perform matching with various matching algorithms. For the placebo test, we discard the treated group, assign the control group as the new placebo-treatment group, and repeat our main specification matching procedure. If the effects are due to the grants, the placebo-treatment should not affect firm performance, thus it should not show any significant effects. In addition, we assign the treatment randomly to the firms, apply the main matching approach, and estimate the ATT. We perform this procedure 10,000 times to empirically obtain the distribution of the ATT estimates. In this way, we do not have to rely on the calculated standard errors (Abadie \& Imbens, 2008) or the normality distribution of the ATT estimates. Moreover, we conduct a sensitivity analysis of the matching approach. We use nearest neighbor matching with two, three, and four control firms per treated firm; nearest neighbor matching with two, three, and four control firms per treated firm, but with a caliper set at $10 \%$ of the standard deviation of the estimated propensity score; radius matching with the same caliper; kernel matching and local linear regressions with the Epanechnikov kernel.

To investigate the grants' mediation effect exerted on capital growth by bank loan growth, a causal mediation analysis is conducted (Imai et al., 2010). The causal mediation effect for each firm $i$ is defined as:

$\delta_{i}(D) \equiv E\left[Y_{i}\left(D, M_{i}(1)\right)-Y_{i}\left(D, M_{i}(0)\right)\right] \quad$ for $D=0,1$

where $D$ gives the treatment status, $Y$ is the potential outcome variable and $M$ is the mediator. The average causal mediation effect (ACME) is the expected difference in the potential outcome when the mediator takes the value that would occur under the treatment condition $\left(M_{i}(1)\right)$ as opposed to the control condition $\left(M_{i}(0)\right)$, while the treatment status itself is held constant. For estimation, we compute two linear models, one with capital growth on the left-hand side and the mediation variable (in our case bank loan growth) on the righthand side as well as $D$; and the other model with the mediator on the left-hand side and $D$ on the right-hand side. In this way, both the direct effect (ADE) of the treatment and the indirect effect (ACME) are estimated.

In causal mediation analysis, an assumption additional to CIA is necessary, i.e., the sequential ignorability assumption. This assumption implies that the mediator is ignorable given the observed treatment and pretreatment confounders. The ignorability of the mediator implies that among those firms that share the same treatment status and pre-treatment characteristics, the mediator can be regarded as if it were randomized. This assumption cannot be directly tested. However, sensitivity analysis (Imai et al., 2010) is conducted to investigate how robust the results are. When the correlation of the residuals $(\rho)$ of the linear models is varied from -1 up to $1, \mathrm{ACME}$ is estimated and checked for the $\rho$ value where ACME changes its sign.

\subsection{Variables used in the analysis}

Our dataset includes a rich set of covariates (Table 2). We used all relevant variables for the public call schemes as well as covariates considered important in the literature to calculate the propensity score.

As covariates, we select relevant firm characteristics that affect not only the selection into treatment but the outcome as well. Some are obvious, such as firm age and size (measured in the number of employees and real turnover); other covariates are proxies for firm characteristics, such as average wage. Firms that pay higher average wages have on average larger capital and cash reserves and thus are more likely to be financially stronger. Either entrepreneurs of such firms may not be interested in applying for the grants or, if they do apply, they may "make more out of it" than do weaker firms. The same holds for firms that have certain knowledgerelated capabilities, indicated by ownership of fixed intangible assets, because these may facilitate more sophisticated production processes, which lead to higher outputs. We also include variables for financial constraints of firms, such as real values of short-term liabilities towards employees, short-term liabilities towards the state, liabilities towards banks, and debt ratio, because firms with higher financial constraints are found to be more vulnerable (Stucki, 2014). This vulnerability can induce firms to seek public aid and is likely to shape how well the firm uses the grant. Debt ratio is included in quadratic form, as firms with more debt might be more motivated to apply for a grant, while those with 
Table. 2 Covariates used for matching

\begin{tabular}{|c|c|}
\hline Variable & Description \\
\hline \multicolumn{2}{|l|}{ Treatment variable } \\
\hline Grant & 1 if the firm received any grant scheme funding, 0 otherwise \\
\hline \multicolumn{2}{|l|}{ Firm characteristics } \\
\hline \multicolumn{2}{|l|}{ Age of the firm } \\
\hline \multicolumn{2}{|l|}{ Squared age of the firm } \\
\hline Ownership of the firm & 1 State, 2 Private, 3 Mixed \\
\hline $\begin{array}{l}\text { Sectors of economy based on technological } \\
\text { intensity }^{\mathrm{a}}\end{array}$ & $\begin{array}{l}1 \text { Agriculture and mining, } 2 \text { High-tech manufacturing, } 3 \text { Mid high-tech } \\
\text { manufacturing, } 4 \text { Mid low-tech manufacturing, } 5 \text { Low-tech manufacturing, } 6 \\
\text { Energy, } 7 \text { Construction, } 8 \text { Knowledge-intensive high-tech services, } 9 \\
\text { Knowledge-intensive other services, } 10 \text { Less knowledge-intensive services }\end{array}$ \\
\hline NUTS $2^{b}$ region of the firm & 1 Continental Croatia, 2 Adriatic Croatia \\
\hline Size of the firm & 1 Micro (1-9 employees), 2 Small (10-49 employees) \\
\hline Trade orientation of the firm & 1 Exporter only, 2 Importer only, 3 Exporter and importer, 4 Domestic market only \\
\hline $\begin{array}{l}\text { Number of people listed for each firm in the } \\
\text { Companies Register }\end{array}$ & 1 One, 2 Two, 3 Three or more \\
\hline $\begin{array}{l}\text { Gender ownership combinations connected to each } \\
\text { firm in the Companies Register }\end{array}$ & 1 Only men, 2 Only women, 3 Men and women \\
\hline \multicolumn{2}{|l|}{ Firm performance characteristics ${ }^{c}$} \\
\hline Labor & $\log (1+$ number of employees $)$ \\
\hline Average wage & $\log (1+$ real average personnel costs $)$ \\
\hline Capital & $\log (1+$ real tangible fixed assets $)$ \\
\hline Fixed intangible assets dummy & Dummy for positive fixed intangible assets; 1 if positive, 0 otherwise \\
\hline Cash reserves & $\log (1+$ real cash and cash equivalents $)$ \\
\hline Debt ratio & (real fixed + current liabilities)/real total assets \\
\hline Squared debt ratio & ((real fixed + current liabilities)/real total assets) squared \\
\hline Liabilities banks & $\log (1+$ real total liabilities towards banks $)$ \\
\hline Turnover & $\log (1+$ real revenue from sales $)$ \\
\hline Intermediate costs & $\log (1+$ real intermediate (material + energy) costs $)$ \\
\hline Export-turnover & Export-to-turnover ratio \\
\hline Import-turnover & Import-to-turnover ratio \\
\hline Real value-added & $\log (1+$ real value-added $)$ \\
\hline Total factor productivity ${ }^{\mathrm{d}}$ & $\log$ (total factor productivity) \\
\hline \multicolumn{2}{|l|}{ Entrepreneur (owner) characteristics } \\
\hline Mean age & Mean age of firm owner(s) \\
\hline Mean age squared & Squared mean age of firm owner(s) \\
\hline Likelihood of pregnancy/motherhood of babies & 1 if woman is 35 years old or older, 0 otherwise \\
\hline \multicolumn{2}{|l|}{ Year } \\
\hline Year & Dummy for each year in our sample \\
\hline
\end{tabular}

Notes: ${ }^{a}$ More specific definitions of these technology sectors are available on request. ${ }^{b}$ According to https://ec.europa. eu/eurostat/web/nuts/background. ${ }^{\mathrm{c}}$ All monetary variables were deflated using year- and sector-specific (NACE 2-digit) Eurostat deflators with base in 2010. Value-added was deflated using value-added deflator. Intermediate inputs (raw materials and energy) were deflated using intermediate input deflator. All other monetary variables were deflated using output deflators. ${ }^{\mathrm{d}}$ Total factor productivity was estimated using Wooldridge's (2009) methodology based on the production function approach using value-added as output, labor and capital as inputs, and intermediate inputs to control for unobservables. As technologies used in the production process differ across different industries, TFP was estimated separately for each NACE 2-digit industry. Log denotes the natural logarithmic transformation 
Table. 3 Outcome variables used in the analysis

\begin{tabular}{|c|c|c|}
\hline Variable & & Description \\
\hline \multicolumn{3}{|l|}{ Firm survival } \\
\hline Active on the market & survive $_{t+q}$ & $\begin{array}{l}\text { Dummy if firm is still on the market in year } t+q \text {, } \\
q \in\{1, \ldots, 5\}\end{array}$ \\
\hline \multicolumn{3}{|l|}{ Output growth } \\
\hline Log sales (turnover) & growth turnover $r_{t-1, t+q}$ & $\begin{array}{l}\text { Real turnover growth from } t-1 \text { to } t+q \text {, } \\
q \in\{1, \ldots, 5\} \\
\log \left(\text { sales }_{t+q}\right)-\log \left(\text { sales }_{t-1}\right)\end{array}$ \\
\hline Log value-added & growth value-added $\mathrm{a}_{t-1, t+q}$ & $\begin{array}{l}\text { Real value-added growth from } t-1 \text { to } t+q \text {, } \\
q \in\{1, \ldots, 5\} \\
\log \left(\text { value added }_{t+q}\right)-\log \left(\text { value }_{\text {added }} \text { al- }\right)\end{array}$ \\
\hline \multicolumn{3}{|l|}{ Labor inputs growth } \\
\hline Log employees & growth employees $t-1, t+q$ & $\begin{array}{l}\text { Number of employees growth from } t-1 \text { to } t+q \text {, } \\
q \in\{1, \ldots, 5\} \\
\log \left(\text { employees }_{t+q}\right)-\log \left(\text { employees }_{t-1}\right)\end{array}$ \\
\hline \multicolumn{3}{|l|}{ Capital inputs growth } \\
\hline Log capital & growth capital $_{t-1, t+q}$ & $\begin{array}{l}\text { Real capital growth from } t-1 \text { to } t+q \\
q \in\{1, \ldots, 5\} \\
\log \left(\text { capital }_{t+q}\right)-\log \left(\text { capital }_{t-1}\right)\end{array}$ \\
\hline Log bank loans & growth liabilities banks $t_{t-1, t+q}$ & $\begin{array}{l}\text { Real total liabilities towards banks growth from } t-1 \text { to } t+q \text {, } \\
q \in\{1, \ldots, 5\} \\
\log \left(\text { liabilities }_{t+q}\right)-\log \left(\text { liabilities }_{t-1}\right)\end{array}$ \\
\hline \multicolumn{3}{|l|}{ Intermediate inputs growth } \\
\hline Log intermediate input costs & growth intermediate costs ${ }_{t-1, t+q}$ & $\begin{array}{l}\text { Real intermediate inputs growth from } t-1 \text { to } t+q \text {, } \\
q \in\{1, \ldots, 5\}, \\
\log \left(\text { intermediate costs }_{t+q}\right)-\log \left(\text { intermediate costs }_{t-1}\right)\end{array}$ \\
\hline \multicolumn{3}{|l|}{ Productivity growth } \\
\hline Log total factor productivity & growth $\mathrm{TFP}_{t-1, t+q}$ & $\begin{array}{l}\text { Real total factor productivity growth from } t-1 \text { to } t+q \text {, } \\
q \in\{1, \ldots, 5\} \\
\log \left(T F P_{t+q}\right)-\log \left(T F P_{t-1}\right)\end{array}$ \\
\hline Log labor productivity (value-added) & growth labor productivity $_{t-1, t+q}$ & $\begin{array}{l}\text { Real labor productivity (value-added) growth from } t-1 \text { to } t+q \text {, } \\
q \in\{1, \ldots, 5\} \\
\log \left(\text { labor productivity }_{t+q}\right)-\log \left(\text { labor productivity }_{t-1}\right)\end{array}$ \\
\hline
\end{tabular}

Note: Log denotes the natural logarithmic transformation

too large a debt ratio may be rejected. The set of covariates also contains measures of productivity, such as real value-added per employee and total factor productivity. These covariates are also assumed to affect firm performance. Firms that are exporters tend to be more productive (Costa et al., 2017) and to have specific entrepreneurial skills and human capital (Brambilla et al., 2012) that can affect both receiving a grant and the potential outcomes. Therefore, we use export-to-turnover ratio and import-to-turnover ratio.

We also include age of the woman entrepreneur, as it relates to aspects of human capital, which affects firm performance and survival (Colombo \& Grilli, 2005). Square of age is added as the grant-awarding agency may view entrepreneurs with too little experience as being too risky for a grant and a saturation effect in this relationship may be present. We also include an indicator denoting women who are less likely to require time off for pregnancy, childbirth, or care of babies. In Croatia, the average age when women have their first child is 29 (Eurostat, 2018). Over $80 \%$ of all mothers in Croatia have only two children, with a gap of about 4 years between them. ${ }^{7}$ Therefore, this indicator is 1 for women at or over 35 , and 0 otherwise.

As is common in the relevant literature, we also control for year, ownership, region, sector, size, trade, and gender composition of the top management team.

Outputs are categorized into six groups (Table 3): firm survival, output growth, labor inputs growth, capital inputs growth, intermediate inputs growth, and productivity growth.

\footnotetext{
${ }^{7}$ Although we have no data for the average time span between two childbirths for women in Croatia, we use data of culturally similar countries such as Italy and Spain from Kreyenfeld et al. (2017). Thus, we conclude that on average, women over 35 years of age are less likely to require time off for pregnancy or childbirth.
} 


\section{Results}

\subsection{Descriptive statistics and matching}

Treated firms are less frequently found in less knowledge-intensive service sectors (33\%) and more frequently in low-technology manufacturing sectors (9\%) than are the control firms before matching, and treated firms have on average acquired larger bank loans (Table 11 in the Appendix). Treated firms more frequently have positive intangible assets $(32 \%)$ and domestic-only trade status (11\%), but are less frequently classified as exporters only.

Treated firms more frequently have three or more employees: $31 \%$ of treated firms have three or more employees compared to $11 \%$ of the potential control firms. At the same time, the treated firms are less frequently single-owned (35\%) compared to all other women-owned firms (58\%). A total of $59 \%$ of treated and $72 \%$ of control firms are owned by women only, while the remaining firms in both subsamples have a gender combination in their ownership structure.

We use a probit model with a dummy variable indicating whether the firm $i$ received the grant in time $t$, $t \in\{2008, \ldots, 2011\}$, and with all firm performance variables, firm characteristics, and entrepreneur characteristics as independent variables (Table 11 in the Appendix). To avoid the problem of simultaneity, the covariates enter the calculations with a lag of one period. Estimation results are provided in Table 12 in the Appendix. We do not interpret the specific findings obtained with the probit model. The purpose of the probit model is to forecast the propensity score and not to interpret the coefficient estimates or their statistical significance. The quality of the matched sample is our main objective here.

The propensity score is then used to find the control group composed of the nearest neighbors to the treated firms. Table 11 in the Appendix shows no significant differences in means of all covariates after matching and considerable decreases in standardized bias. The observed empirical distributions of the covariates and the propensity score can be accepted as sufficiently equal for treated and control firms. The necessary balancing property is thus achieved.

\subsection{Average treatment effect on the treated}

Women entrepreneurship grants yield a positive effect on firm survival compared to control firms 5 years after treatment (Table 4), which is roughly in line with the results of Gennari and Lotti (2013), who investigated firm survival rates in Italy after receipt of grant for women-owned start-ups.

Grants induce positive output additionality in sales and value-added in the years $t+3$ and $t+4$. The treatment has a positive significant effect on employment, suggesting a positive effect on labor input additionality. Concerning capital inputs, the data show that grants induce significant positive capital input additionality. Treated firms also exhibit significantly higher growth rates in bank loans. We do not find evidence for statistically significant additionality in intermediate inputs and productivity growth. Considering these findings, we can claim that hypothesis 1 is partially confirmed.

The placebo test demonstrates the robustness of our findings (Table 13 in the Appendix). Figure 1 in the Appendix provides the empirical distribution of the estimated ATTs for 10,000 replications for each statistically significant ATT in Table 4 . The gray solid line marks the estimated ATT reported in Table 4, while black dashed lines represent the top and bottom $5 \%$ of the distribution. All estimated ATTs are in the far-right tail of their distribution, supporting the conclusion that there is only a small probability that they occur by chance. In addition, Table 14 in the Appendix shows the results of the alternative matching approaches. All findings confirm the robustness of the main results.

Table 5 shows the indirect effects of grants on capital growth through bank loans. The average causal mediation effect (ACME) is the part of the ATT that is transmitted through bank loan growth, while the average direct effect (ADE) is the direct effect of treatment on capital growth. We find a strong and significant grant indirect effect in all 5 years after the treatment, implying that the grant induced a positive effect on bank loans, which accounted for a substantial proportion of the capital growth effect. This highlights the importance of the mediation effect of grants through bank loans. Hence, hypothesis 2 is confirmed.

The sensitivity analysis indicates that the sign of the ACME would be maintained unless the sensitivity parameter $\rho$ is greater than $0.17(t+1), 0.22(t+2), 0.22(t$ $+3), 0.24(t+4)$, and $0.21(t+5)$. Hence, these findings support the robustness of the estimates in Table 5 against possible unobserved confounders, as a possible confounder must explain a substantial proportion of the variance in both regressions. 
Table. 4 Treatment effects of women entrepreneurship grants on firm performance

\begin{tabular}{|c|c|c|c|c|c|}
\hline \multirow[t]{2}{*}{ Outcome variables } & \multicolumn{5}{|l|}{ ATT (SE) } \\
\hline & $t+1$ & $t+2$ & $t+3$ & $t+4$ & $t+5$ \\
\hline \multicolumn{6}{|l|}{ Firm survival } \\
\hline Active on the market & $0.001(0.010)$ & $0.004(0.012)$ & $0.012(0.015)$ & $0.021(0.017)$ & $0.029 *(0.019)$ \\
\hline \multicolumn{6}{|l|}{ Output growth } \\
\hline Log sales (turnover) & $0.068(0.043)$ & $0.041(0.052)$ & $0.099 *(0.057)$ & $0.118 *(0.063)$ & $0.061(0.066)$ \\
\hline Log value-added & $0.060(0.044)$ & $0.031(0.052)$ & $0.107 *(0.059)$ & $0.130 * *(0.065)$ & $0.081(0.064)$ \\
\hline \multicolumn{6}{|l|}{ Labor inputs growth } \\
\hline Log employees & $0.076 * * *(0.023)$ & $0.092 * * *(0.025)$ & $0.103 * * *(0.030)$ & $0.080 * *(0.033)$ & $0.098^{* * *}(0.037)$ \\
\hline \multicolumn{6}{|l|}{ Capital inputs growth } \\
\hline Log capital & $0.333 * *(0.164)$ & $0.317 *(0.201)$ & $0.491 * *(0.216)$ & $0.421 *(0.219)$ & $0.561 * *(0.239)$ \\
\hline Log bank loans & $1.260 * * *(0.369)$ & $1.618 * * *(0.414)$ & $1.378 * *(0.429)$ & $1.38 * *(0.448)$ & $1.125 * *(0.460)$ \\
\hline \multicolumn{6}{|l|}{ Intermediate inputs growth } \\
\hline Log intermediate input costs & $0.022(0.061)$ & $0.004(0.071)$ & $0.016(0.075)$ & $0.065(0.078)$ & $0.041(0.078)$ \\
\hline \multicolumn{6}{|l|}{ Productivity growth } \\
\hline Log total factor productivity & $-0.021(0.05)$ & $-0.041(0.047)$ & $0.019(0.053)$ & $0.049(0.056)$ & $-0.019(0.055)$ \\
\hline Log labor productivity & $-0.038(0.050)$ & $-0.061(0.055)$ & $0.001(0.051)$ & $0.046(0.053)$ & $-0.017(0.052)$ \\
\hline
\end{tabular}

Notes: $* p<0.1, * * p<0.05, * * * p<0.01$, two-sided $p$ values. Standard errors (SE) are based on Abadie and Imbens (2008); log denotes the natural logarithmic transformation

Finally, we consider heterogeneous effects due to the entrepreneur's age or, more specifically, the associated characteristics of the women entrepreneurs. Therefore, we split the sample into women below and above 40 years of age. The differences in important characteristics between the two groups are pronounced. Younger women entrepreneurs, compared to those aged 40 or above, own on average younger (7.4 years versus 12.1 years) and smaller firms (5.3 employees versus 6.3 employees). They are thus more likely to have shorter and weaker credit histories. In addition, young women entrepreneurs own less capital-the average tangible fixed assets (a proxy for capital) are significantly lower for young women entrepreneurs $(112,645$ EUR) than for women entrepreneurs over 40 (159,675 EUR). The same holds for liabilities to banks $(61,853$ EUR versus
79,375 EUR). Therefore, we consider our cut-off point, which we chose originally as mean age of the women entrepreneurs in our sample, as appropriate to use in these subsamples as a proxy for more or less experienced women entrepreneurs.

We then re-estimate the ATT (Table 6). We find that the grant effects are indeed different for these two groups. The grants influence the survival of young women's firms. In the control group, more firms went bankrupt although these firms had similar prerequisites. Concerning the other output variables, the treated firms do not significantly differ from the remaining control firms. The effects on the outcome variables (output growth; labor, capital, and intermediate input growth; long-term productivity) are pronounced for more experienced women entrepreneurs. This can possibly be explained by the fact that these women might have

Table. 5 Mediation results of treatment through bank loans growth on capital growth

\begin{tabular}{|c|c|c|c|c|c|c|c|c|c|c|}
\hline \multirow{2}{*}{$\begin{array}{l}\text { Effect } \\
\text { ACME }\end{array}$} & \multicolumn{2}{|l|}{$t+1$} & \multicolumn{2}{|l|}{$t+2$} & \multicolumn{2}{|l|}{$t+3$} & \multicolumn{2}{|l|}{$t+4$} & \multicolumn{2}{|l|}{$t+5$} \\
\hline & 0.097 & $* * *$ & 0.174 & $* * *$ & 0.153 & $* * *$ & 0.161 & $* * *$ & 0.125 & $* * *$ \\
\hline $\mathrm{ADE}$ & 0.236 & * & 0.142 & & 0.338 & $*$ & 0.260 & & 0.434 & $*$ \\
\hline Total effect & 0.333 & $* *$ & 0.316 & $*$ & 0.491 & $* *$ & 0.421 & $* *$ & 0.559 & $* *$ \\
\hline
\end{tabular}

Notes: Confidence intervals are obtained via 10,000 simulations. ${ }^{*} p<0.1, * * p<0.05$, $* * * p<0.01$, two-sided $p$ values. The coefficients for the controls are omitted for the sake of brevity and are available on request 
worked longer in the same industry and were thus able to build larger industry-specific human capital, superior business networks, and business skills (Ganotakis, 2012). Against this background of women entrepreneurs, the grant effect is most successful. This confirms hypothesis 3 .

\subsection{Cost-benefit analysis}

The estimated treatment effects for women below and at or above 40 years of age (Table 6 ) enable us to make a costbenefit analysis with common "back-of-the-envelope" calculation (Czarnitzki \& Lopes-Bento, 2013). On the cost side, the amount of public funds provided for women entrepreneurs' business development projects was 0.4 million EUR for more experienced women entrepreneurs (2008-2011 period; Table 10 in the Appendix). The grant scheme had on average a positive effect on obtaining bank loans of about 6416 EUR for more experienced women per firm at $t+1$, as indicated in Table 7. This value multiplied by the number of total public grants awarded $\left(n_{T}=327\right.$; Table 10 in the Appendix) gives 2.1 million EUR. This denotes the higher value of financing due to the grant scheme for more experienced women entrepreneurs. In sum, the grant scheme costs and the grant-induced bank loans for the women entrepreneurship projects amount to 2.5 million EUR for the more experienced women entrepreneurs. On the benefits side, this financial support leads on average to an increase in value-added per firm at time $t$ +1 of 16,753 EUR for more experienced women (Table 7). Therefore, we estimate the total benefits (multiplied by 327 ) at 5.5 million EUR. Thus, the estimated benefits are a factor 2.2 larger than the sum of public costs and grant-induced bank loans 1 year after the grants were provided. In the long run, 5 years after the grants were distributed $(t+5)$, this effect is still at that level (the factor is 2.1).

No significant output additionality is found for firms owned by younger women entrepreneurs, other than positive survival effects as described in the previous section and positive effects of bank loans in the first 2 years after receiving a subsidy. Although the effect on outcome additionality of young women entrepreneurs is lacking, the outcome produced by more experienced women entrepreneurs outweighs the public cost of the grant scheme, thus confirming hypothesis 4 .

Table. 6 Heterogeneous treatment effects dependent on women entrepreneurs' experience

\begin{tabular}{|c|c|c|c|c|c|c|c|c|c|c|}
\hline \multirow[t]{3}{*}{ Outcome variables } & \multicolumn{10}{|l|}{ ATT } \\
\hline & \multicolumn{5}{|c|}{ Women below age $40\left(n_{T}=156^{\mathrm{a}}\right)$} & \multicolumn{5}{|c|}{ Women at or above age $40\left(n_{T}=327^{\mathrm{a}}\right)$} \\
\hline & $t+1$ & $t+2$ & $t+3$ & $t+4$ & $t+5$ & $t+1$ & $t+2$ & $t+3$ & $t+4$ & $t+5$ \\
\hline \multicolumn{11}{|l|}{ Firm survival } \\
\hline Active on the market & 0.019 & 0.026 & 0.032 & $0.045^{*}$ & $0.071 *$ & -0.006 & 0.009 & 0.003 & 0.012 & 0.012 \\
\hline \multicolumn{11}{|l|}{ Output growth } \\
\hline Log sales (turnover) & 0.036 & 0.026 & 0.043 & 0.023 & -0.009 & $0.105^{* *}$ & 0.062 & $0.102 *$ & $0.132 *$ & $0.100 *$ \\
\hline Log value-added & -0.003 & -0.060 & -0.058 & -0.034 & -0.098 & $0.119 * * *$ & 0.077 & $0.157 * *$ & $0.180 * *$ & $0.137 *$ \\
\hline \multicolumn{11}{|l|}{ Labor inputs growth } \\
\hline Log employees & 0.044 & 0.052 & 0.046 & 0.013 & -0.017 & $0.056^{* * *}$ & $0.057 * *$ & $0.075 * *$ & $0.063 *$ & $0.073 * *$ \\
\hline \multicolumn{11}{|l|}{ Capital inputs growth } \\
\hline Log capital & 0.013 & 0.278 & 0.087 & 0.270 & -0.058 & 0.208 & 0.056 & 0.252 & $0.422 *$ & $0.528 *$ \\
\hline Log bank loans & $1.708 * * *$ & $1.668 * *$ & 0.629 & 0.657 & -0.043 & $0.782 *$ & $1.466 * * *$ & $1.195 * *$ & $1.279 * *$ & $0.926^{*}$ \\
\hline \multicolumn{11}{|l|}{ Intermediate inputs growth } \\
\hline Log intermediate input costs & -0.039 & -0.038 & -0.042 & 0.028 & -0.029 & $0.095^{*}$ & 0.058 & 0.044 & 0.061 & 0.103 \\
\hline \multicolumn{11}{|l|}{ Productivity growth } \\
\hline Log total factor productivity & -0.105 & -0.068 & -0.063 & -0.062 & -0.010 & $0.077 *$ & 0.042 & 0.098 & $0.147 *$ & 0.066 \\
\hline Log labor productivity & -0.135 & -0.112 & -0.104 & -0.047 & 0.006 & 0.063 & 0.020 & 0.078 & $0.152 * *$ & 0.064 \\
\hline
\end{tabular}

Notes: $* p<0.1, * * p<0.05, * * * p<0.01$, two-sided $p$ values. Standard errors are based on Abadie and Imbens (2008); log denotes the natural logarithmic transformation. Balancing property after matching is satisfied. For the sake of brevity, we do not report standard errors or balancing property results, but they are available on request. ${ }^{\mathrm{a}} n_{T}$ denotes the number of treated firms in each subgroup 
Table. 7 Quantification of heterogeneous treatment effects of the women entrepreneurship grant scheme by women entrepreneurs' experience

\begin{tabular}{|c|c|c|c|c|c|}
\hline Outcome variables & $t+1$ & $t+2$ & $t+3$ & $t+4$ & $t+5$ \\
\hline \multicolumn{6}{|c|}{ Women at or above age $40\left(n_{T}=327^{\mathrm{a}}\right)$} \\
\hline Real turnover & 16,538 & $-{ }^{b}$ & 16,062 & 21,113 & - \\
\hline Real value-added & 16,753 & - & 22,638 & 26,217 & 19,555 \\
\hline Number of employees & 0.23 & 0.24 & 0.31 & - & 0.30 \\
\hline Real capital & - & - & - & 10,538 & 13,969 \\
\hline Real total liabilities towards banks & 6416 & 18,028 & 12,468 & 14,036 & 8251 \\
\hline Real intermediate inputs & 5819 & - & - & - & - \\
\hline
\end{tabular}

Notes: We estimate the effects for the sample of treated firms in our analysis. All monetary variables are expressed in EUR. 1 EUR $\sim 7.42$ Croatian kuna (HRK). ${ }^{\mathrm{a}} n_{T}$ denotes the number of treated firms. ${ }^{\mathrm{b}}$ We report only significant effects

\section{Discussion and conclusion}

In this paper, we discuss a public policy instrument targeting exclusively women entrepreneurs, which was used in Croatia during the recession after the financial crisis of 2008. Although the full economic impact of COVID-19 is still uncertain, there are several reasons to believe that this recession is going to affect women entrepreneurs excessively. Firstly, women face challenges due to (partial) school closures and limited service-job supply (e.g., childcare or daycare facilities). The time requirements for household functioning have increased at the expense of work time available for one's own firm. Secondly, women-owned firms, mostly SMEs, are predominantly found in consumer-oriented sectors that are the most affected by closures and necessary adaptations caused by physical distance measures (OECD, 2020). Since women generally run companies with lower capitalization, they are more dependent on self-financing and internal financing. They have fewer financial reserves. A drop in revenue due to COVID-19 restrictions and related lower economic activity has a direct impact on the financing of both business and living. Finally, most women-owned businesses, especially in the service sector, often rely on contractors rather than on employees. Only about a quarter of self-employed women have employees (OECD, 2019). This excludes them from the government's support packages, which are limited to companies with employees. For these reasons, our investigation of the effectiveness of the grant scheme does not only contribute to the question of whether small-scale support can make a measurable contribution to firm behavior changes. Rather, it is a concrete indication of whether such an instrument could provide efficient public support, especially for women entrepreneurs, in the difficult economic circumstances ahead. The characteristics of the entrepreneurs in question (e.g., shortage of time due to care obligations or lack of knowledge required on financing applications) are not specific to entrepreneurs in Croatia. We expect that in other countries of the European Union, similar grant schemes can create comparable positive changes in the behavior of entrepreneurs. A generalization of the findings beyond women entrepreneurs to entrepreneurs with comparable entrepreneurial constraints seems reasonable, but such policy instruments are a topic for future research.

Policy makers are aware of the economic potential that can develop from supporting women entrepreneurs. Nevertheless, in the coming years, it will be difficult to maintain exceptionally high levels of public funding over the longer term. Specific to our case is the fact that the grant amount itself is too small to be directly invested in capital or labor as a means of increasing business performance. The subsidy is too small in monetary terms, and it is not targeted at supporting investment projects that may influence the performance of the companies through a certification effect. Rather, the grant serves as an incentive for entrepreneurs to reassess the economic situation of the firm or possible investment opportunities. Activities such as the development of business plans, entrepreneurial training, and obtaining childcare are supported, allowing women entrepreneurs either to spend more time in the firm or to use external expertise to obtain information. When women entrepreneurs are able to gather more information (and thus reduce their risk aversion or increase their confidence), they are more likely to increase their demand for business finance and to make investments. The impact of these investments is observed in firm input and output performance measures. 
For the entire sample, we find increased output additionality. The consideration of age and associated characteristics of women entrepreneurs is decisive for impact assessment, as the heterogeneity of the effects is pronounced. The average age of the women entrepreneurs in the study by De Mel et al. (2012) is just around our cut-off point for the investigation of heterogeneous effects (40 years). A significant effect on firm output measures, however, is evident in our case for more experienced women entrepreneurs only. This can be explained by the higher industry-specific human capital of more experienced women entrepreneurs that allows them to better exploit business opportunities and connections. We find statistical evidence for output additionality concerning sales, value-added, and intermediate inputs growth. For younger women entrepreneurs, who have less capital, the effect of the grants results in capital investments that slightly increase the chance of firm survival. Our results are in line with De Mel et al. (2012).

We conduct a cost-benefit analysis of the grant scheme with standard "back-of-the-envelope" calculation in the short and long term. In the short term, the yearly benefits outweigh the grant costs (defined by public money plus additional bank loans) by a factor of 2.2 for more experienced women entrepreneurs. The positive effects for more experienced women entrepreneurs are quite persistent in the long run. Benefits outweigh the total grant costs for more experienced women entrepreneurs by a factor of 2.1 . The cost-benefit analysis of this study shows benefits (and thus cost effectiveness) similar to those achieved by business development grants for new firms, SMEs, and exporters in the same country (Dvouletý et al., 2020; Srhoj \& Walde, 2020).

To sum up, this study makes several important points. (1) It provides robust evidence for the positive impact of small business development grants aimed exclusively at women entrepreneurs. The benefits of the grant scheme outweigh its costs. (2) We show that such a grant scheme designed to foster women entrepreneurs is particularly effective for more experienced women entrepreneurs. (3) Part of the positive firm effects was achieved through using bank financing opportunities, i.e., by increasing financial demand.

The analyzed matching grant scheme is an example of a policy instrument that allocates very small grants to entrepreneurs and is therefore inexpensive enough to be administered to a large population of eligible firms, while still being effective. The instrument discussed in this paper was targeted to women entrepreneurs, but it is conceivable that other groups of undercapitalized firms could be helped with similarly designed instruments. The main point of differentiation is that instead of providing money, the instrument helps the entrepreneur to acquire skills needed to successfully apply for funding with banks or other sources. As the instrument discussed in this study was quite effective in a long-lasting recession, such an approach may also be considered for the post-COVID-19 period.

This study is not without limitations and open questions for future research. A standard challenge in using matching methodologies is the possibility of an unobserved covariate affecting both the outcome and the selection into treatment, the most obvious one being the effect that social environment exerts on women entrepreneurs. Given the available data, we controlled for entrepreneur-level characteristics such as age, gender combination, and size of the founding team. Using a rather rich firm-level dataset, we were also able to proxy for human capital (e.g., average wage) and wealth (e.g., short- and long-term debts, turnover). Nonetheless, one possible area for future research is to capture the effects of further personal characteristics of women entrepreneurs, such as their previous work experience, levels of their human and social capital, their wealth, number of children, or partner's employment status and income. Due to the small sample size, our heterogeneous analysis was only possible for two subsamples comprising less experienced and more experienced women entrepreneurs. Further splits may be necessary to capture the gradient more appropriately in the acquired human, social, or financial capital. Therefore, as we cannot rule out differences in such variables between the investigated groups, this must be left for future research. Finally, we analyzed the average treatment effects on the treated firms, while awarded grants may have also generated positive spillovers to other firms, such as consultants, suppliers of equipment, or kindergartens, which we did not estimate. An additional interesting area for future research is to obtain historical data on firms' applications for bank loans to be able to disentangle more precisely between behavioral additionality and certification effect. Lastly, including the grant amount itself as a treatment variable in the analysis would allow us to investigate optimal grant sizes. For our grant scheme, the range of the grant amounts was too small to obtain robust results or to allow conclusions for different grant amounts. We leave this important question for future analyses of grant schemes. 


\section{Appendix}

Table. 8 Women entrepreneurship grant scheme(s) description

\begin{tabular}{|c|c|c|c|}
\hline $\begin{array}{l}\text { Grant scheme } \\
\text { name }\end{array}$ & Subsidized activities & Minimum conditions & Min. and max. amounts \\
\hline $\begin{array}{l}\text { Women } \\
\text { entrepreneur- } \\
\text { ship } \\
2008,2009 \text {, } \\
2010,2011 \text {, } \\
2012\end{array}$ & $\begin{array}{l}\text { Co-financing the business plan } \\
\text { development, consulting services, } \\
\text { documentation for bank loans, } \\
\text { entrepreneurial training (apart from } \\
\text { study costs), business registration costs, } \\
\text { purchasing equipment, tools, } \\
\text { inventory, and protective equipment, } \\
\text { babysitting costs, kindergarten costs, } \\
\text { child educator costs or extended school } \\
\text { stay costs for the period of } 1 \text { year }\end{array}$ & $\begin{array}{l}\text { Firms in bankruptcy or liquidation } \\
\text { procedure and those with unpaid } \\
\text { debts towards the state or } \\
\text { employees are not eligible } \\
\text { Surplus in previous year (turnover } \\
\text { higher than costs) } \\
\text { Headquarters in the Republic of } \\
\text { Croatia } \\
\text { At least } 1 \text { full-time employee (in- } \\
\text { cluding the owner) } \\
\text { If the firm received the grant } \\
\text { before-a statement of funds } \\
\text { spent as planned in the } \\
\text { previous year }\end{array}$ & $\begin{array}{l}\text { The support amounted up to } 75 \% \text { of } \\
\text { costs (VAT excluded) } \\
\text { Min. amount was set at } 673 \text { EUR } \\
\text { from } 2009 \text { onwards (there was no } \\
\text { min. amount in } 2008 \text { ) and max. } \\
\text { amount at } 10,768 \text { EUR } \\
\text { In } 2012 \text { min. amount was set at } 6,732 \\
\text { EUR and max. amount at } 20,190 \\
\text { EUR with } 100 \% \text { support provided } \\
\text { (VAT excluded) }\end{array}$ \\
\hline
\end{tabular}

Note: All monetary variables are expressed in EUR. 1 EUR 7.42 Croatian kuna (HRK)

Source: Authors based on MINPO $(2013,2014)$

Table. 9 Women entrepreneurship grant scheme(s) descriptive statistics, overall

\begin{tabular}{|c|c|c|c|c|c|c|c|c|c|c|c|c|c|c|c|c|}
\hline \multirow[t]{2}{*}{ Year } & \multicolumn{8}{|c|}{ All grants } & \multicolumn{8}{|c|}{ Final sample } \\
\hline & Grants & Amount & Mean (SD) & Min. & Max. & Q1 & Med. & Q3 & Grants & Amount & Mean (SD) & Min. & Max. & Q1 & Med. & Q3 \\
\hline 2008 & 526 & 571,539 & 1087 (776) & 296 & 5385 & 674 & 1011 & 1011 & 217 & 230,764 & $1063(704)$ & 296 & 5385 & 741 & 1011 & 1011 \\
\hline 2009 & 98 & 226,254 & 2309 (1476) & 673 & 6058 & 1348 & 2022 & 2695 & 23 & 52,504 & $2283(1311)$ & 673 & 6058 & 1348 & 2022 & 2695 \\
\hline 2010 & 305 & 416,953 & 1367 (1245) & 673 & 10,770 & 674 & 1011 & 1348 & 117 & 164,445 & 1405 (1359) & 673 & 10,770 & 674 & 1011 & 1348 \\
\hline 2011 & 331 & 438,232 & 1324 (1076) & 673 & 6731 & 674 & 809 & 1348 & 127 & 150,645 & $1186(794)$ & 673 & 6731 & 674 & 809 & 1348 \\
\hline 2012 & 24 & 448,553 & $\begin{array}{l}18,691 \\
\quad(2986)\end{array}$ & 9932 & 20,194 & 18,541 & 20,216 & 20,216 & - & - & - & - & - & - & - & - \\
\hline Total & 1284 & $2,100,876$ & 1636 & - & - & - & - & - & 484 & 598,358 & 1,236 & - & - & - & - & - \\
\hline
\end{tabular}

Note: All monetary variables are expressed in EUR. 1 EUR 7.42 Croatian kuna (HRK)

Source: Authors based on MINPO (2013, 2014) 


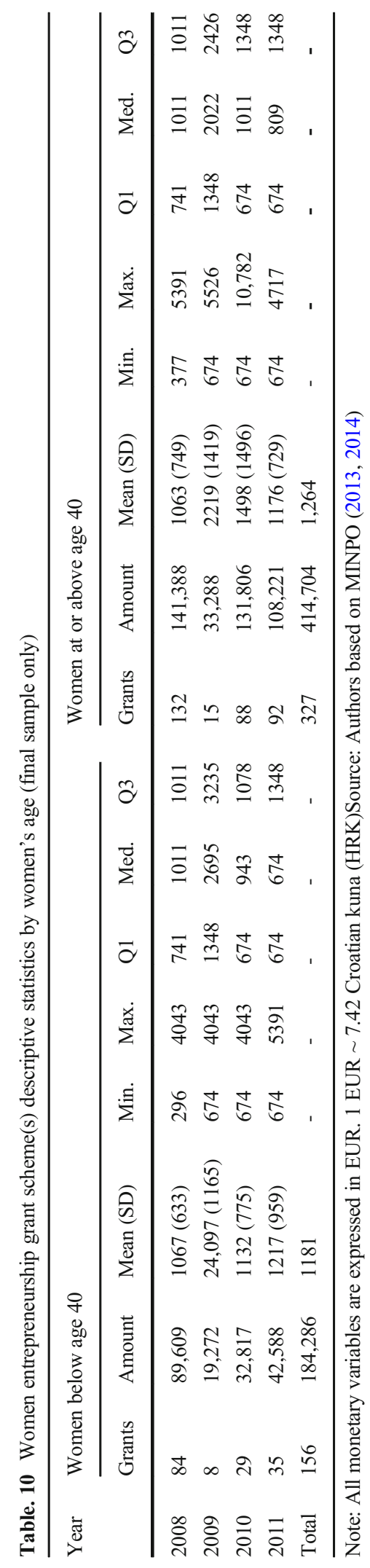




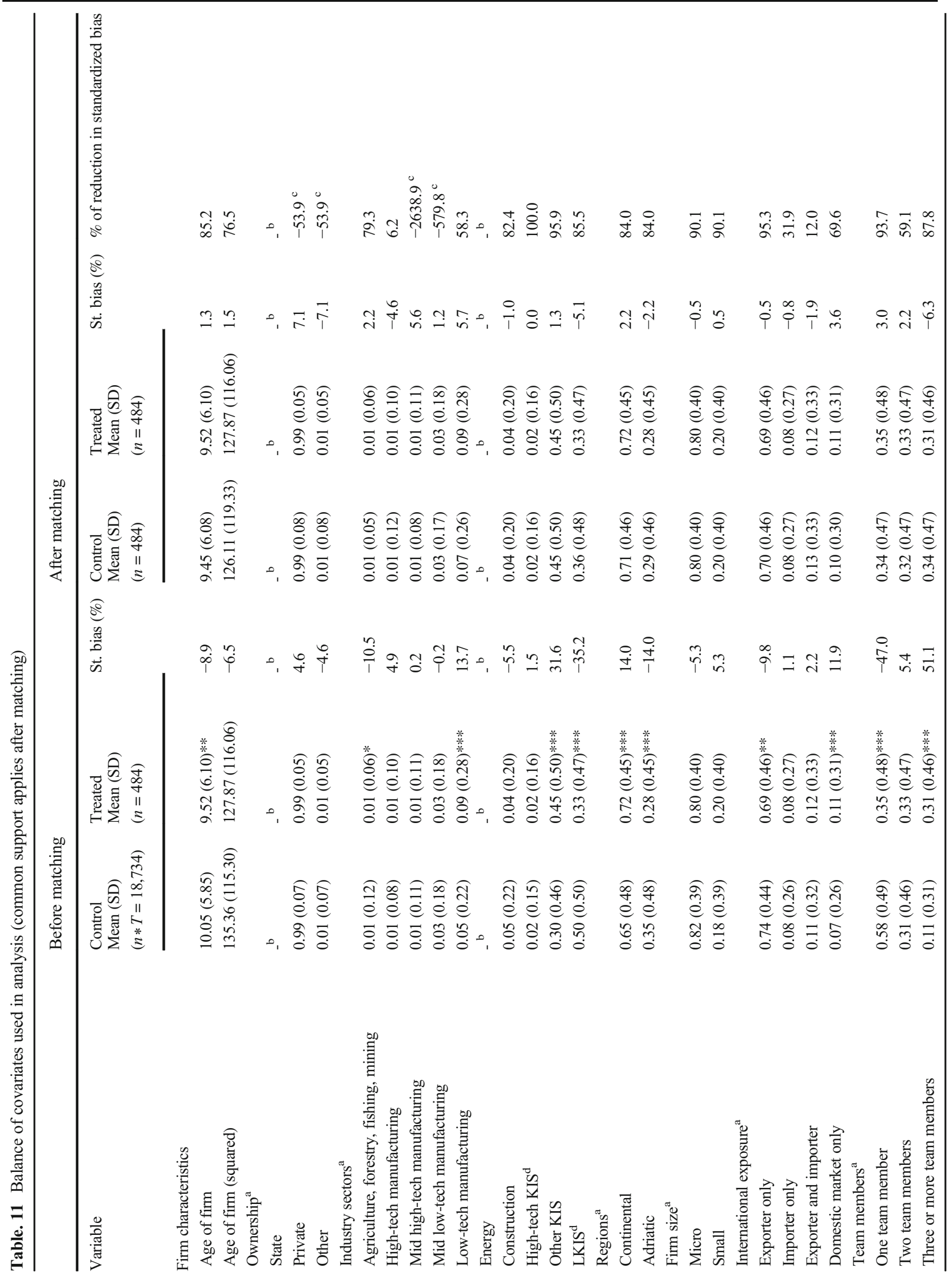




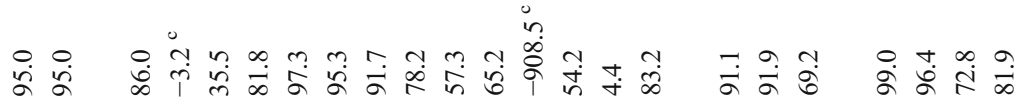

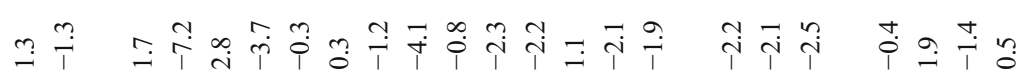

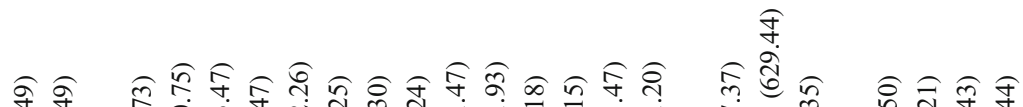

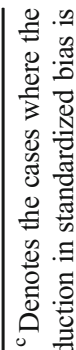

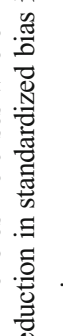

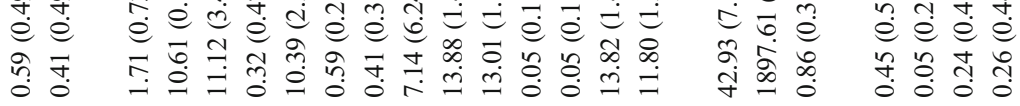

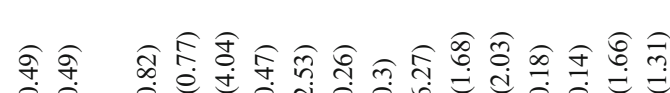

$\underset{n}{\stackrel{c}{\infty}}$

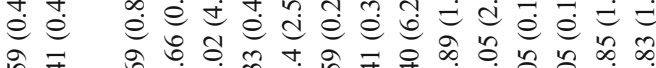

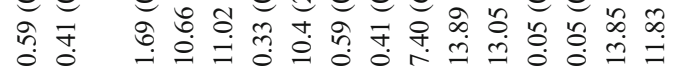

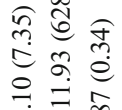

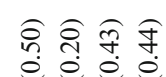

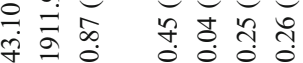

苛

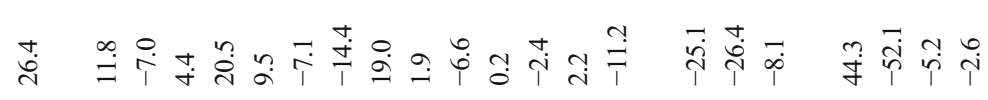

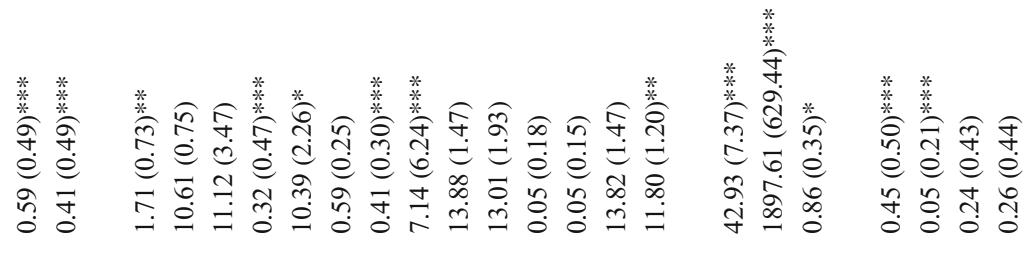

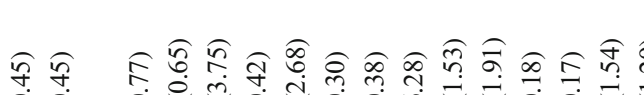

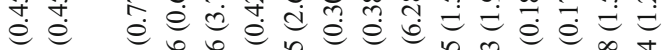

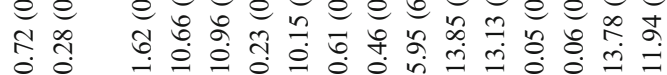

๖

0
$\infty$
है

¿. है

辛离究

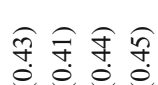

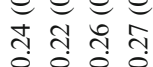

$$
\text { . }
$$


Table. 12 Results of the probit model

\begin{tabular}{|c|c|c|}
\hline Variable $^{\mathbf{a}}$ & Estimated coefficients & Marginal effects \\
\hline \multirow[t]{2}{*}{ Age of firm } & $-0.028 * *$ & $-0.001 * *$ \\
\hline & $(0.014)$ & $(0.001)$ \\
\hline \multirow[t]{2}{*}{ Age of firm (squared) } & $0.002 * *$ & $0.000 * *$ \\
\hline & $(0.001)$ & $(0.000)$ \\
\hline \multirow[t]{2}{*}{$\log ($ number of employees $)$} & -0.019 & -0.001 \\
\hline & $(0.066)$ & $(0.003)$ \\
\hline \multirow[t]{2}{*}{$\log$ (real average wage) } & $-0.196^{* * *}$ & $-0.010 * * *$ \\
\hline & $(0.043)$ & $(0.002)$ \\
\hline \multirow[t]{2}{*}{$\log ($ real capital) } & -0.010 & -0.000 \\
\hline & $(0.008)$ & $(0.000)$ \\
\hline \multirow[t]{2}{*}{ Fixed intangible assets dummy } & $0.170 * * *$ & $0.008 * * *$ \\
\hline & $(0.048)$ & $(0.002)$ \\
\hline \multirow[t]{2}{*}{$\log$ (real cash reserves) } & 0.011 & 0.001 \\
\hline & $(0.010)$ & $(0.000)$ \\
\hline \multirow[t]{2}{*}{ Debt ratio } & $1.663 * * *$ & $0.082 * * *$ \\
\hline & $(0.324)$ & $(0.016)$ \\
\hline \multirow[t]{2}{*}{ Debt ratio (squared) } & $-1.466^{* * *}$ & $-0.072 * * *$ \\
\hline & $(0.260)$ & $(0.013)$ \\
\hline \multirow[t]{2}{*}{$\log ($ real liabilities towards banks) } & $0.010 * *$ & $0.000 * *$ \\
\hline & $(0.004)$ & $(0.000)$ \\
\hline \multirow[t]{2}{*}{$\log ($ real turnover $)$} & 0.123 & 0.006 \\
\hline & $(0.080)$ & $(0.004)$ \\
\hline \multirow[t]{2}{*}{$\log ($ real intermediate costs $)$} & $-0.090 * * *$ & $-0.004 * * *$ \\
\hline & $(0.032)$ & $(0.002)$ \\
\hline \multirow[t]{2}{*}{ Export-to-turnover ratio } & -0.068 & -0.003 \\
\hline & $(0.135)$ & $(0.007)$ \\
\hline \multirow[t]{2}{*}{ Import-to-turnover ratio } & -0.138 & -0.007 \\
\hline & $(0.164)$ & $(0.008)$ \\
\hline \multirow[t]{2}{*}{$\log ($ real value-added $)$} & $0.166^{*}$ & $0.008 *$ \\
\hline & $(0.090)$ & $(0.004)$ \\
\hline \multirow[t]{2}{*}{$\log$ (total factor productivity) } & $-0.156^{* * *}$ & $-0.008 * * *$ \\
\hline & $(0.056)$ & $(0.003)$ \\
\hline \multirow[t]{2}{*}{ Entrepreneur age } & 0.016 & 0.001 \\
\hline & $(0.034)$ & $(0.002)$ \\
\hline \multirow[t]{2}{*}{ Entrepreneur age (squared) } & -0.000 & -0.000 \\
\hline & $(0.000)$ & $(0.000)$ \\
\hline \multirow[t]{3}{*}{ Likelihood of pregnancy/motherhood of babies } & 0.061 & 0.003 \\
\hline & $(0.108)$ & $(0.005)$ \\
\hline & $20,392^{b}$ & $20,392^{b}$ \\
\hline McFadden pseudo & 0.140 & 0.140 \\
\hline
\end{tabular}

Notes: $* \mathrm{p}<0.1, * * \mathrm{p}<0.05, * * * \mathrm{p}<0.01$, two-sided $\mathrm{p}$ values. Mean variance inflation factor (VIF) is 10.86 (as mentioned in the text, we do not interpret the significance of the coefficients; we simply use the estimated probability score). ${ }^{\text {a }}$ In this model, we also control for effects of years, ownership, region, sector, size, trade exposure, gender, and team. However, these results are omitted for the sake of brevity and presentation purposes, but they are available on request. ${ }^{\mathrm{b}}$ There is a difference between the number of observations in Table A4 (20,392) and the number of observations in Table A3 $(18,734+484=19,218)$, because we remove some observations after probit estimations, as they do not have common support 
Table. 13 Treatment effects (placebo test results)

\begin{tabular}{|c|c|c|c|c|c|}
\hline \multirow[t]{2}{*}{ Outcome variables } & \multicolumn{5}{|l|}{ ATT (SE) } \\
\hline & $t+1$ & $t+2$ & $t+3$ & $t+4$ & $t+5$ \\
\hline \multicolumn{6}{|l|}{ Firm survival } \\
\hline Active on the market & $-0.017(0.011)$ & $-0.006(0.012)$ & $-0.006(0.015)$ & $-0.008(0.018)$ & $0.001(0.020)$ \\
\hline \multicolumn{6}{|l|}{ Output growth } \\
\hline Log sales (turnover) & $-0.037(0.046)$ & $-0.032(0.052)$ & $-0.052(0.059)$ & $-0.066(0.067)$ & $-0.064(0.070)$ \\
\hline Log value-added & $-0.035(0.048)$ & $-0.015(0.054)$ & $-0.058(0.060)$ & $-0.044(0.074)$ & $-0.033(0.074)$ \\
\hline \multicolumn{6}{|l|}{ Labor inputs growth } \\
\hline Log employees & $-0.027(0.022)$ & $-0.045(0.026)$ & $-0.072(0.049)$ & $-0.061(0.035)$ & $-0.077(0.058)$ \\
\hline \multicolumn{6}{|l|}{ Capital inputs growth } \\
\hline Log capital & $-0.134(0.159)$ & $-0.044(0.192)$ & $-0.115(0.228)$ & $-0.097(0.240)$ & $-0.286(0.259)$ \\
\hline Log bank loans & $-0.539(0.372)$ & $-0.424(0.415)$ & $-0.590(0.425)$ & $-0.723(0.440)$ & $-0.625(0.462)$ \\
\hline \multicolumn{6}{|l|}{ Intermediate inputs growth } \\
\hline Log intermediate input costs & $0.030(0.061)$ & $0.042(0.071)$ & $0.040(0.072)$ & $0.017(0.077)$ & $0.009(0.080)$ \\
\hline \multicolumn{6}{|l|}{ Productivity growth } \\
\hline Log total factor productivity & $-0.007(0.051)$ & $0.009(0.050)$ & $-0.017(0.055)$ & $-0.011(0.067)$ & $0.055(0.069)$ \\
\hline Log labor productivity & $0.015(0.052)$ & $0.030(0.049)$ & $0.018(0.052)$ & $0.017(0.063)$ & $0.070(0.067)$ \\
\hline
\end{tabular}

Notes: $* p<0.1, * * p<0.05, * * * p<0.01$, two-sided $p$ values. Standard errors are based on Abadie and Imbens (2008) but are omitted to save space. They are available on request. Log denotes the natural logarithmic transformation 


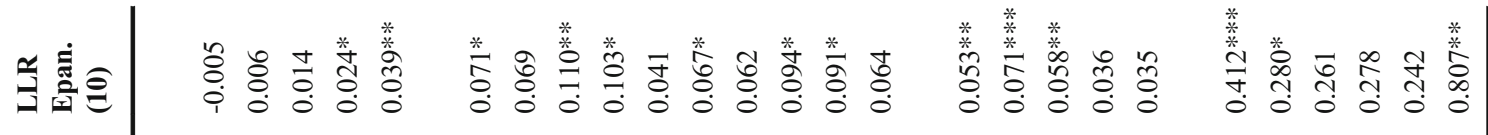

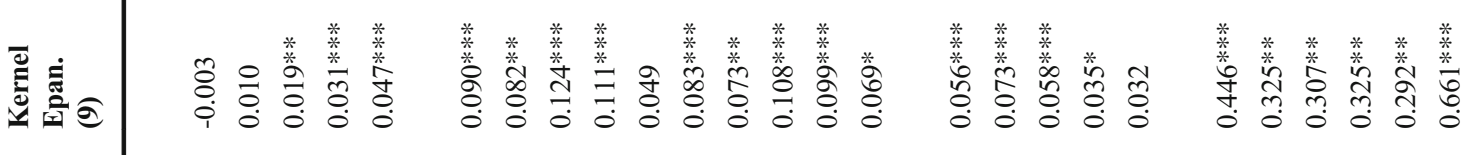

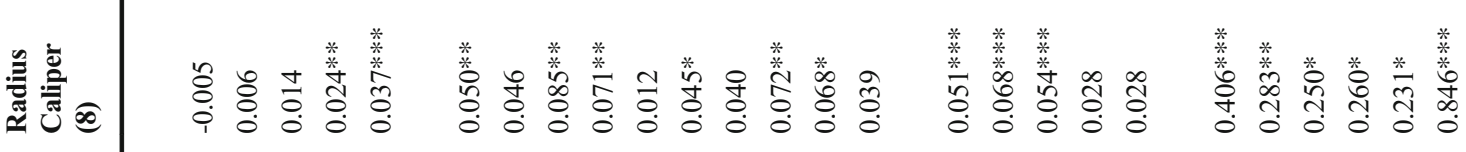

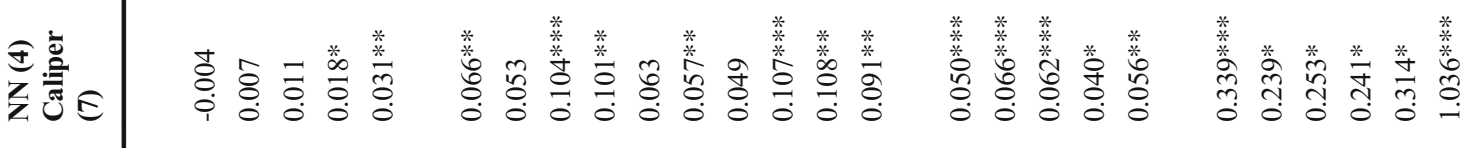

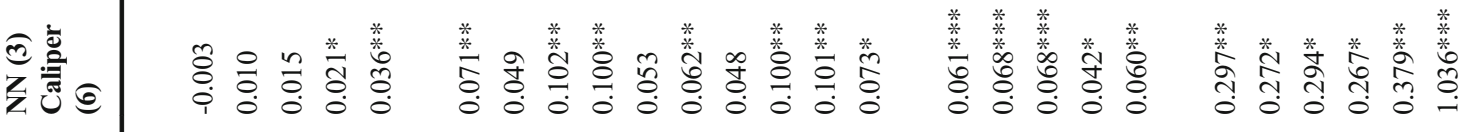

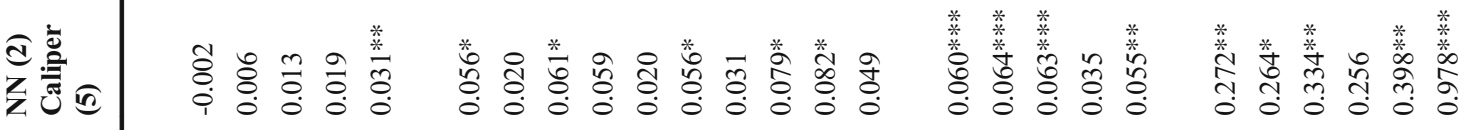

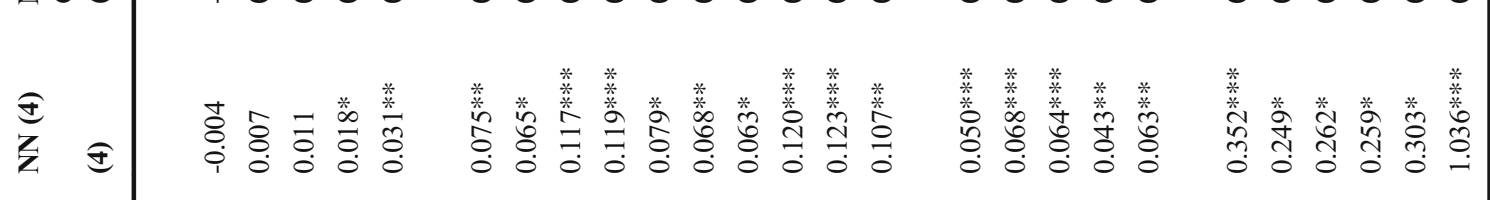

$\frac{00}{4}$

$\stackrel{\substack{\Xi \\:}}{\stackrel{0}{0}}$

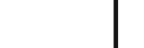

产

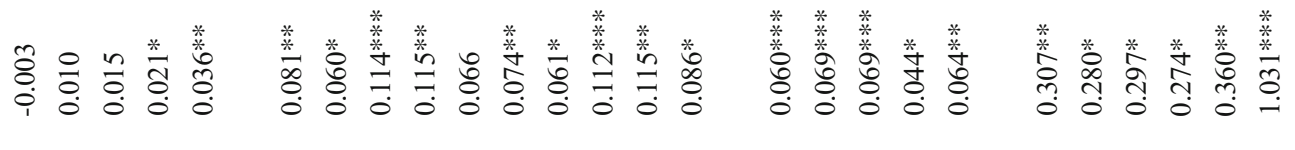

离

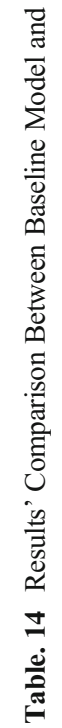

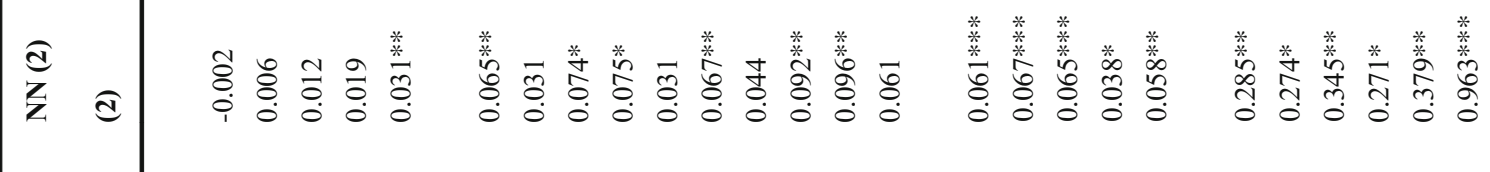

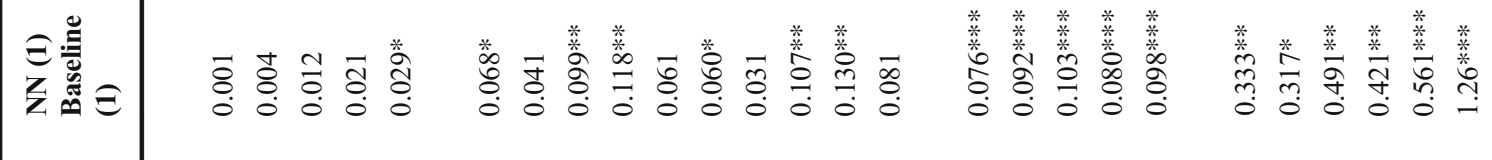




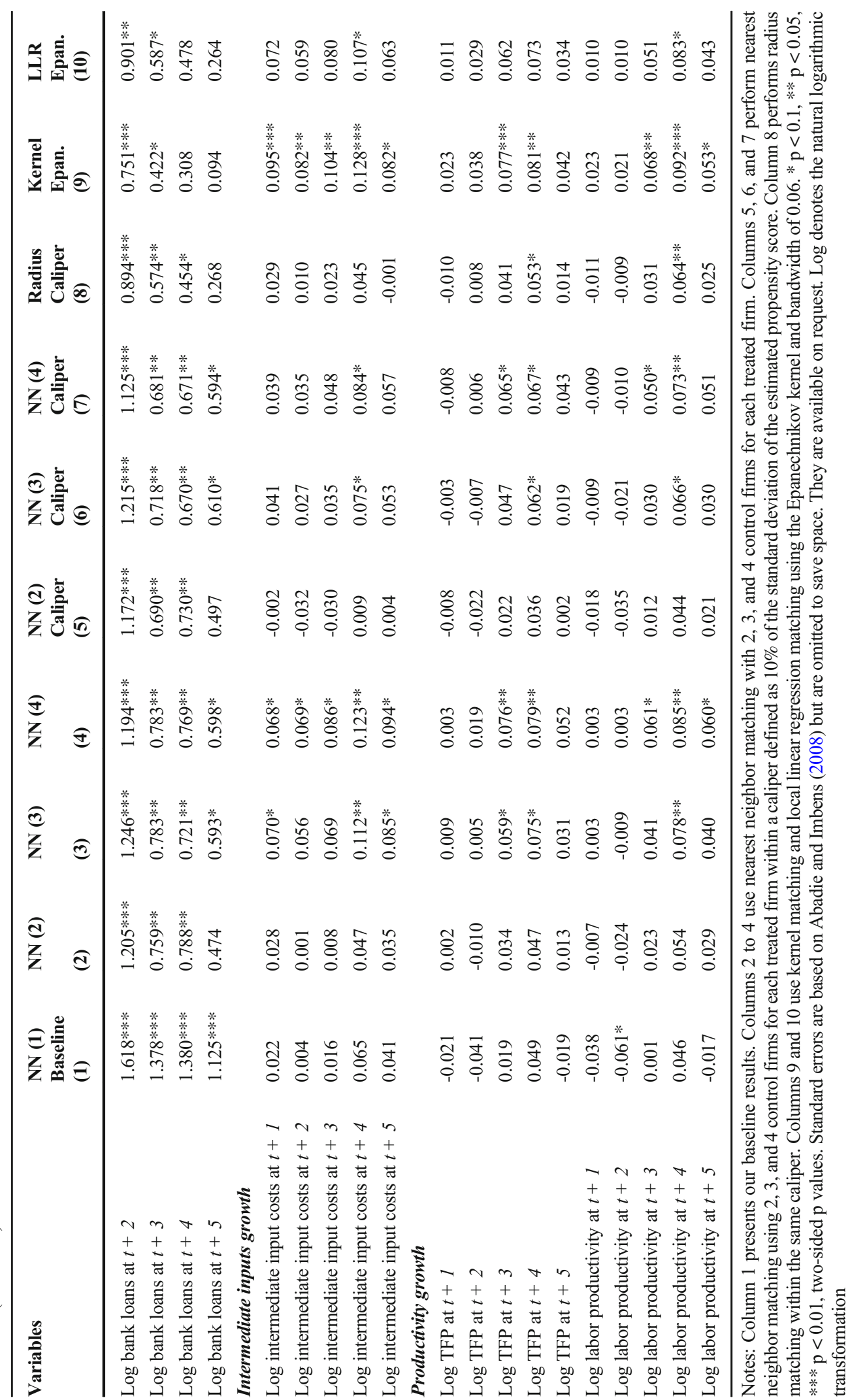



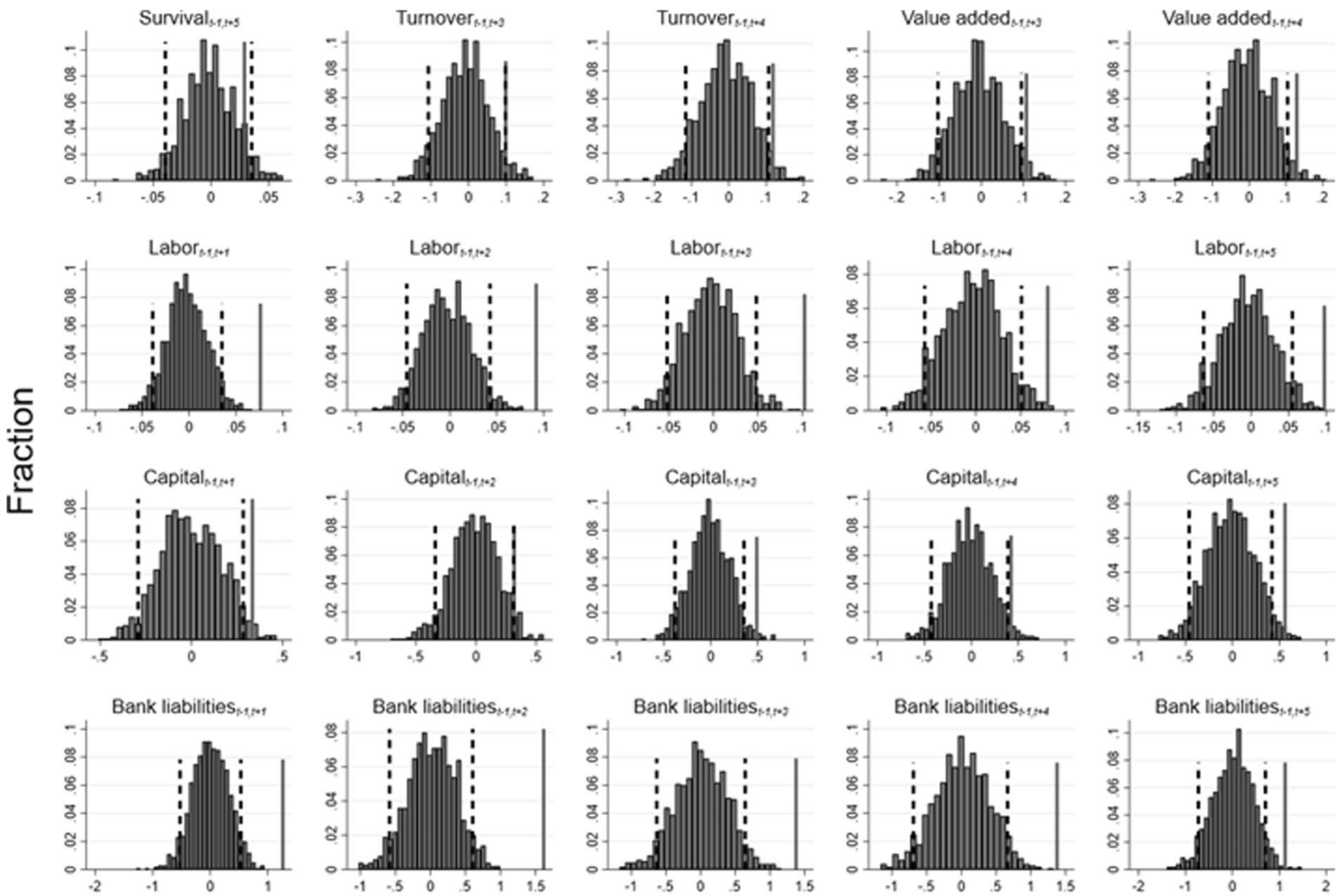

ATTs

Fig. 1 Empirical ATT distribution of placebo test with 10,000 replications

Acknowledgements We are grateful for the comments and suggestions made by the participants at the 2019 Diana International Research Conference (held on June 2-5, 2019, at Babson College in Wellesley, MA, USA) and by the participants at the 2019 Innovation Management, Entrepreneurship and Sustainability Conference (held on May 30-31, 2019, at University of Economics, Prague, Czech Republic). We thank Loukas Balafoutas from University of Innsbruck for reading an earlier version of the paper and for providing valuable comments. Our thanks also go to Mary Heaney Margreiter, native-speaker interpreter/translator/editor, and to Doris Baničević, interpreter/translator/editor, for language editing of the manuscript.

\section{Availability of data and material Not applicable.}

Code availability Not applicable.

\section{References}

MINPO. (2013). Ministry of entrepreneurship and crafts of the Republic of Croatia. Poduzetnički impuls - Plan poticanja poduzetništva i obrtništva [Entrepreneurial impulse - Plan of supporting entrepreneurship and crafts]. Zagreb. Croatia.
MINPO. (2014). Ministry of entrepreneurship and crafts of the Republic of Croatia. Strategija razvoja poduzetništva žena u Republici Hrvatskoj 2014 - 2020. [Women entrepreneurship development strategy in Republic of Croatia 2014 - 2020]. Zagreb. Croatia.

OECD. (2004). Organisation for economic co-operation \& development. Women entrepreneurship: Issues and policies. Available at: http://www.oecd.org/cfe/smes/31919215.pdf. Accessed 17 November 2019.

OECD. (2019). Organisation for economic co-operation \& development. Development Centre. Gender, Institutions and Development database (GID-DB) 2019.

OECD. (2020). Organisation for economic co-operation \& development. Women at the core of the fight against COVID-19 crises. Tackling Coronavirus (Covid-19) Contributing to a global effort.

Abadie, A., \& Imbens, G. W. (2008). On the failure of the bootstrap for matching estimators. Econometrica, 76(6), 1537-1557 https://doi.org/10.3982/ECTA6474.

Ahl, H., \& Nelson, T. (2015). How policy positions women entrepreneurs: A comparative analysis of state discourse in Sweden and the United States. Journal of Business Venturing, 30(2), 273-291. https://doi.org/10.1016/j. jbusvent.2014.08.002.

Alesina, A., Lotti, F., \& Mistrulli, P. E. (2013). Do women pay more for credit? Evidence from Italy. Journal of the 
European Economic Association, 11(1), 45-66. https://oi. org/10.1111/j.1542-4774.2012.01100.x.

Allen, W. D., \& Curington, W. P. (2014). The self-employment of men and women: What are their motivations? Journal of Labor Research, 35(2), 143-161 https://doi.org/10.1007 /s12122-014-9176-6.

Backman, M. (2014). Human capital in firms and regions: Impact on firm productivity. Papers in Regional Science, 93(3), 557-575 https://doi.org/10.1111/pirs.12005.

Bartlett, W. (2016). The failure of government policies to drive entrepreneurial performance in Croatia. In C. C. Williams \& A. Gurtoo (Eds.), Routledge Handbook of Entrepreneurship in Developing Countries (pp. 99-112) ISBN 9781138849143.

Bellucci, A., Borisov, A., \& Zazzaro, A. (2010). Does gender matter in bank-firm relationships? Evidence from small business lending. Journal of Banking \& Finance, 34(12), 29682984 https://doi.org/10.1016/j.jbankfin.2010.07.008.

Berge, L. I. O., \& Pires, A. J. G. (2020). Gender, formality, and entrepreneurial success. Small Business Economics, 55, 881900. https://doi.org/10.1007/s11187-019-00163-8.

Block, J., Sandner, P., \& Spiegel, F. (2015). How do risk attitudes differ within the group of entrepreneurs? The role of motivation and procedural utility. Journal of Small Business Management, 53(1), 183-206 https://doi.org/10.1111/jsbm.12060.

Borghans, L., Golsteyn, B., Heckman, J., \& Meijers, H. (2009). Gender differences in risk aversion and ambiguity aversion. Journal of the European Economic Association, 7(2/3), 649$658 \mathrm{https}: / / w w w . j s t o r . o r g /$ stable/40282781.

Bosma, N. (2013). The Global Entrepreneurship Monitor (GEM) $\&$ its impact on entrepreneurship research. Foundations and Trends in Entrepreneurship, 9(2), 143-248 https://doi. org/10.1561/0300000033.

Brambilla, I., Lederman, D., \& Porto, G. (2012). Exports, export destinations, \& skills. American Economic Review, 102(7), 3406-3438 https://doi.org/10.1257/aer.102.7.3406.

Brookings. (2020). Businesses owned by women and minorities have grown. Will COVID-19 undo that? Retrieved from https://www. brookings.edu/research/businesses-owned-by-women-andminorities-have-grown-will-covid-19-undo-that/

Brush, C., Edelman, L. F., Manolova, T., \& Welter, F. (2019). A gendered look at entrepreneurship ecosystems. Small Business Economics, 52(2), 393-408. https://doi. org/10.1007/s11187-018-9992-9.

Cardella, G. M., Hernández-Sánchez, B. R., \& Sánchez-García, J. C. (2020). Women entrepreneurship: A systematic review to outline the boundaries of scientific literature. Frontiers in Psychology, 11, 1557 https://doi.org/10.3389/fpsyg.2020.01557.

Carter, S., Shaw, E., Lam, W., \& Wilson, F. (2007). Gender, entrepreneurship, and bank lending: The criteria and processes used by bank loan officers in assessing applications. Entrepreneurship Theory and Practice, 31(3), 427-444 https://doi.org/10.1111/j.1540-6520.2007.00181.x.

Carter, S., Mwaura, S., Ram, M., Trehan, K., \& Jones, T. (2015). Barriers to ethnic minority and women's enterprise: Existing evidence, policy tensions and unsettled questions. International Small Business Journal: Researching Entrepreneurship, 33(1), 49-69 https://doi.org/10.1177 /0266242614556823.

Cerqua, A., \& Pellegrini, G. (2017). Industrial policy evaluation in the presence of spillovers. Small Business Economics, 49(3), 671-686 https://doi.org/10.1007/s11187-017-9855-9.
Coleman, S. (2002). Constraints faced by women small business owners: Evidence from the data. Journal of Developmental Entrepreneurship, 7(2), 151-174.

Colombo, M. G., \& Grilli, L. (2005). Founders' human capital and the growth of new technology-based firms: A competencebased view. Research policy, 34(6), 795-816 https://doi. org/10.1016/j.respol.2005.03.010.

Costa, S., Pappalardo, C., \& Vicarelli, C. (2017). Internationalization choices and Italian firm performance during the crisis. Small Business Economics, 48(3), 753769 https://doi.org/10.1007/s11187-016-9799-5.

Cowling, M., Marlow, S., \& Liu, W. (2019). Gender and bank lending after the global financial crisis: Are women entrepreneurs safer bets? Small Business Economics, Epub ahead of print, (13 April 2019). https://doi.org/10.1007/s11187-01900168-3.

Criscuolo, C., Martin, R., Overman, H. G., \& Van Reenen, J. (2019). Some causal effects of an industrial policy. American Economic Review, 109(1), 48-85 https://doi. org/10.1257/aer.20160034.

Croson, R., \& Gneezy, U. (2009). Gender differences in preferences. Journal of Economic Literature, 47(2), 448-474 https://doi.org/10.1257/jel.47.2.448.

Czarnitzki, D., \& Lopes-Bento, C. (2013). Value for money? New microeconometric evidence on public $\mathrm{R} \& \mathrm{D}$ grants in Flanders. Research Policy, 42(1), 76-89 https://doi. org/10.1016/j.respol.2012.04.008.

De Mel, S., McKenzie, D., \& Woodruff, C. (2012). One-time transfers of cash or capital have long-lasting effects on microenterprises in Sri Lanka. Science, 335(6071), 962-966 https://doi.org/10.1126/science.1212973.

Dvouletý, O., Srhoj, S., \& Pantea, S. (2020). Public SME grants and firm performance in European Union: A systematic review of empirical evidence. Small Business Economics, Epub ahead of print, (14 January 2020). https://doi. org/10.1007/s11187-019-00306-x.

European Commission. (2014). Statistical Data on Women Entrepreneurs in Europe. Publications Office of the European Union.

Eurostat. (2018). Women in EU have first child on average at, 29 Retrieved from https://ec.europa.eu/eurostat/documents /2995521/8774296/3-28032018-AP-EN.pdf/fdf8ebdf-a6a44153-9ee9-2f05652d8ee0.

Faccio, M., Marchica, M. T., \& Mura, R. (2016). CEO gender, corporate risk-taking, and the efficiency of capital allocation. Journal of Corporate Finance, 39, 193-209 https://doi. org/10.1016/j.jcorpfin.2016.02.008.

Foss, L., Henry, C., Ahl, H., \& Mikalsen, G. H. (2019). Women's entrepreneurship policy research: A 30-year review of the evidence. Small Business Economics, 53(2), 409-429. https://doi.org/10.1007/s11187-018-9993-8.

Fréchette, G. R., Schotter, A., \& Trevino, I. (2017). Personality, information acquisition, and choice under uncertainty: An experimental study. Economic Inquiry, 55(3), 1468-1488 https://doi.org/10.1111/ecin.12438.

Friedson-Ridenour, S., \& Pierotti, R. S. (2019). Competing priorities: Women's microenterprises and household relationships. World Development, 121, 53-62. https://doi. org/10.1016/j.worlddev.2019.04.008.

Ganotakis, P. (2012). Founders' human capital and the performance of UK new technology based firms. Small Business 
Economics, 39(2), 495-515 https://doi.org/10.1007/s11187010-9309-0.

Gennari, E., \& Lotti, F. (2013). Female entrepreneurship and government policy: Evaluating the impact of subsidies on firms' survival. In Bank of Italy Occasional Paper No. 192. https://doi.org/10.2139/ssrn.2303710.

Guzman, J., \& Kacperczyk, A. O. (2019). Gender gap in entrepreneurship. Research Policy, 48(7), 1666-1680. https://doi. org/10.1016/j.respol.2019.03.012.

Heckman, J. J., Ichimura, H., \& Todd, P. (1998). Matching as an econometric evaluation estimator. The Review of Economic Studies, 65(2), 261-294. https://doi.org/10.1111/1467-937 X.00044.

Henry, C., Orser, B., Coleman, S., \& Foss, L. (2017). Women's entrepreneurship policy: A 13 nation cross-country comparison. International Journal of Gender and Entrepreneurship, 9(3), 206-228. https://doi.org/10.4337/9781785364624.00018.

Howell, S. T. (2017). Financing innovation: Evidence from R\&D grants. American Economic Review, 107(4), 1136-1164. https://doi.org/10.1257/aer.20150808.

Huang, J., \& Kisgen, D. J. (2013). Gender and corporate finance: Are male executives overconfident relative to female executives? Journal of Financial Economics, 108(3), 822-839. https://doi.org/10.1016/j.jfineco.2012.12.005.

Imai, K., Keele, L., \& Tingley, D. (2010). A general approach to causal mediation analysis. Psychological methods, 15(4), 309-334. https://doi.org/10.1037/a0020761.

Kreyenfeld, M., Geisler, E., Martín, T. C., Hannemann, T., HeintzMartin, V., Jalovaara, M., Kulu, H., Meggiolaro, S., Mortelmans, D., Pasteels, I., Seiz, M., \& Solaz, A. (2017). Social policies, separation, and second birth spacing in Western Europe. Demographic Research, 37(37), 1245$1274 \mathrm{https}: / / \mathrm{www} . j \mathrm{stor}$. org/stable/26332224.

Leitch, C., Welter, F., \& Henry, C. (2018). Women entrepreneurs' financing revisited: Taking stock and looking forward. Venture Capital, 20(2), 103-114 https://doi.org/10.1080 /13691066.2018.1418624.

Lim, Y., \& Suh, C. S. (2019). Where is my partner? The role of gender in the formation of entrepreneurial businesses. Small Business Economics, 52(1), 131-151 https://doi.org/10.1007 /s11187-018-0027-3.

Martí, J., \& Quas, A. (2018). A beacon in the night: Government certification of SMEs towards banks. Small Business Economics, 50(2), 397-413 https://doi.org/10.1007/s11187016-9828-4.

Ministry of Entrepreneurship and Crafts of the Republic of Croatia. MINPO. (2013). Poduzetnički impuls - Plan poticanja poduzetništva $i$ obrtništva [Plan of supporting entrepreneurship and crafts]. Government of the Republic of Croatia.

Neumeyer, X., Santos, S. C., Caetano, A., \& Kalbfleisch, P. (2018). Entrepreneurship ecosystems and women entrepreneurs: A social capital and network approach. Small Business Economics, 53(2), 475-489 https://doi.org/10.1007/s11187018-9996-5.

Pandey, S., \& Amezcua, A. S. (2020). Women's business ownership and women's entrepreneurship through the lens of US federal policies. Small Business Economics., 54, 1123-1152 https://doi.org/10.1007/s11187-018-0122-5.

Pellegrini, G., \& Muccigrosso, T. (2017). Do subsidized new firms survive longer? Evidence from a counterfactual approach.
Regional Studies, 51(10), 1483-1493. https://doi. org/10.1080/00343404.2016.1190814.

Robb, A., \& Walken, J. D. (2002). Firm, owner, and financing characteristics: Differences between female- and maleowned small businesses. In Federal Reserve Working Paper 2002-18. https://doi.org/10.2139/ssrn.306800.

Rosenbaum, P. R., \& Rubin, D. B. (1983). The central role of the propensity score in observational studies for causal effects. Biometrika, 70(1), 41-55 https://doi.org/10.1093 /biomet/70.1.41.

Rubin, D. B. (1977). Assignment to treatment group on the basis of a covariate. Journal of Educational Statistics, 2(1), 1-26 https://doi.org/10.3102/10769986002001001.

Schubert, R., Brown, M., Gysler, M., \& Brachinger, H. W. (1999). Financial decision-making: Are women really more riskaverse? American Economic Review, 89(2), 381-385 https://doi.org/10.1257/aer.89.2.381.

Schulz, E., Chowdhury, S., \& Van de Voort, D. (2013). Firm productivity moderated link between human capital and compensation: The significance of task-specific human capital. Human Resource Management, 52(3), 423-439. https://doi. org/10.1002/hrm.21537.

Špička, J. (2018). How does public investment support change the capital structure and productivity of small enterprises? An empirical study of the food industry. International Food and Agribusiness Management Review, 21(8), 1045-1059 https://doi.org/10.22434/IFAMR2018.0009.

Srhoj, S., \& Walde, J. (2020). Getting ready for EU Single Market: The effect of export-oriented grant schemes on firm performance. Structural Change and Economic Dynamics, 52, 279-293 https://doi.org/10.1016/j.strueco.2019.11.001.

Srhoj, S., Lapinski, M., \& Walde, J. (2020). Impact evaluation of business development grants on SME performance. Small Business Economics, 1-17 https://doi.org/10.1007/s11187020-00348-6.

Srhoj, S., Škrinjarić, B., \& Radas, S. (2021). Bidding against the odds? The impact evaluation of grants for young micro and small firms during the recession. Small Business Economics, 56, 83-103 https://doi.org/10.1007/s11187-019-00200-6.

Stucki, T. (2014). Success of start-up firms: the role of financial constraints. Industrial and Corporate Change, 23(1), 25-64 https://doi.org/10.1093/icc/dtt008.

Terjesen, S., Bosma, N., \& Stam, E. (2016). Advancing public policy for high-growth, female, and social entrepreneurs. Public Administration Review, 76(2), 230-239 https://doi. org/10.1111/puar.12472.

Vitezić, V., Srhoj, S., \& Perić, M. (2018). Investigating industry dynamics in a recessionary transition economy. South East European Journal of Economics and Business, 13(1), 43-67 https://doi.org/10.2478/jeb-2018-0003.

Wooldridge, J. M. (2009). On estimating firm-level production functions using proxy variables to control for unobservables. Economics Letters, 104(3), 112-114 https://doi.org/10.1016 /j.econlet.2009.04.026.

Publisher's note Springer Nature remains neutral with regard to jurisdictional claims in published maps and institutional affiliations. 